\title{
High elevation watersheds in the southern Appalachians: Indicators of sensitivity to acidic deposition and the potential for restoration through \\ liming.
}

Jennifer D. Knoepp ${ }^{* a}$, James M. Vose ${ }^{\mathrm{b}}$, William A Jackson ${ }^{\mathrm{c}}$, Katherine J. Elliott ${ }^{\mathrm{a}}$, and Stan

Zarnoch $^{\mathrm{c}}$

*-corresponding author; jknoepp@fs.fed.us

a- USDA Forest Service, Southern Research Station, Center for Watershed Research, Coweeta

Hydrologic Laboratory, 3160 Coweeta Lab Road, Otto, NC 28763

b- USDA Forest Service, Southern Research Station, Center for Integrated Forest Science and Synthesis, Raleigh, NC 27695

c- USDA Forest Service, National Forests of North Carolina, Asheville, NC 28801

d- USDA Forest Service, Southern Research Station, Forest Inventory and Analysis, Clemson,

SC 29634 


\section{Abstract}

Southern Appalachian high elevation watersheds have deep rocky soils with high organic matter content, different vegetation communities, and receive greater inputs of acidic deposition compared to low elevation sites within the region. Since the implementation of the Clean Air Act Amendment in the 1990s, concentrations of acidic anions in rainfall have declined.

However, some high elevation streams continue to show signs of chronic to episodic acidity, where acid neutralizing capacity (ANC) ranges from 0 to $20 \mu \mathrm{eq} \mathrm{L}^{-1}$. We studied three $3^{\text {rd }}$ order watersheds (North River in Cherokee National Forest, Santeetlah Creek in Nantahala National Forest, and North Fork of the French Broad in Pisgah National Forest) and selected four to six $1^{\text {st }}$ order catchments within each watershed to represent a gradient in elevation (849-1526 m) and a range in acidic stream ANC values $\left(11-50 \mu \mathrm{eq} \mathrm{L}^{-1}\right)$. Our objectives were to, 1) identify biotic, physical and chemical catchment parameters that could be used as indices of stream $\mathrm{ANC}, \mathrm{pH}$ and $\mathrm{Ca}: \mathrm{Al}$ molar ratios, and 2) estimate the lime required to restore catchments from the effects of excess acidity and increase base cation availability. We quantified each catchment's biotic, physical, and chemical characteristics and collected stream, O-horizon, and mineral soil samples for chemical analysis seasonally for one year. Using repeated measures analysis, we examined variability in stream chemistry and catchment characteristics; we used a nested split-plot design to identify catchment characteristics that were correlated with stream chemistry. Watersheds differed significantly and the catchments sampled provided a wide range of stream chemical, biotic, physical and chemical characteristics. Variability in stream ANC, $\mathrm{pH}$, and Ca:Al molar ratio were significantly correlated with catchment vegetation characteristics (basal area, tree height, and tree diameter) as well as O-horizon nitrogen and aluminum concentrations. Total soil 
24 carbon and calcium (an indicator of parent material), were significant covariates for stream 25 ANC, pH and Ca:Al molar ratios. Lime requirement estimates did not differ among watersheds 26 but this data will help select catchments for future restoration and lime application studies. Not 27 surprisingly, this work found many vegetation and chemical characteristics that were useful 28 indicators of stream acidity. However, some expected relationships such as concentrations of 29 mineral soil extractable $\mathrm{Ca}$ and $\mathrm{SO}_{4}$ were not significant. This suggests that an extensive test of 30 these indicators across the southern Appalachians will be required to identify high elevation 31 forested catchments that would benefit from restoration activities.

32 Keywords: acid deposition, liming, acid neutralizing capacity, high elevation forest, forest soil, 33 forest floor, O-horizon. 


\section{Introduction}

Ecosystem responses to acidic deposition were a significant concern and a focus of research in

37 the later part of the $20^{\text {th }}$ century in the eastern United States (Johnson et al., 1982; Johnson et al., 1992). The Clean Air Act of 1970 and the Clean Air Act Amendments of 1990 (CAAA), along with other emission reduction regulatory programs, have resulted in declining concentrations of sulfate $\left(\mathrm{SO}_{4}\right)$ and hydrogen $\left(\mathrm{H}^{+}\right)$in wet deposition, consistent with the declines in sulfur dioxide $\left(\mathrm{SO}_{2}\right)$ emissions across the eastern US (Driscoll et al., 2003). For example, the U.S.

42 Environmental Protection Agency (2015) reported that the three-year average for 1989-1991 and 2009-2011 sulfur (S) and total nitrogen $(\mathrm{N})$ deposition (dry plus wet) decreased by 55\% in the eastern US. Similarly, NADP reported a decline in $\mathrm{SO}_{4}$ deposition in most southern Appalachian monitoring sites beginning in 1990 (NADP, 2007). This decline was also evident in data from

46 Great Smoky Mountains National Park (Pardo and Duarte, 2007) and the Coweeta Hydrologic 47 Laboratory in southwestern North Carolina, US (Knoepp, unpublished data). Despite reductions atmospheric deposition (Greaver et al., 2012). For example, some high elevation streams in the eastern U.S. continue to show signs of chronic to episodic acidity (Sullivan et al., 2007).

51 Modeled patterns of $\mathrm{SO}_{4}+$ nitrate $\left(\mathrm{NO}_{3}\right)$ deposition and ecosystem critical loads, exceeded the 52 capacity of forest soils in approximately $17 \%$ of forested sites across the conterminous United 53 States, (McNulty et al., 2007) and numerous aquatic ecosystems in the southern Appalachians 54 (McDonnell et al., 2014). 
57 edges, aspect, and vegetation composition (Weathers et al., 2000; Sullivan et al., 2007) with an estimated a $4-6$ fold range in spatial variability (Weathers et al., 2006). Within the southern Appalachian Mountains high elevation sites receive higher rainfall (Swift Jr. et al., 1988) and greater inputs of nutrient and pollutant deposition (Swank, 1988; Swank and Vose, 1997; Sullivan et al., 2007) than low elevation sites. High elevation watersheds also have deep rocky

62 soils with high organic matter content (Knoepp and Swank, 1998; Knoepp et al., 2000) and 63 vegetation communities similar to forests in the northeastern U.S. (Elliott et al., 1999; Elliott and 64 Swank, 2008). The deposition of $\mathrm{SO}_{4}$ and $\mathrm{NO}_{3}$ anions and their movement through the forest 65 floor (soil O-horizon) and mineral soil profile results in the removal of base cations (calcium $66(\mathrm{Ca})$, magnesium $(\mathrm{Mg})$, and potassium $(\mathrm{K})$ from soils. When base cations are removed from 67 soils without adequate buffering capacity, soil $\mathrm{pH}$ decreases and aluminum (Al) is solubilized resulting in increased $\mathrm{Al}$ concentrations in soil solution and streams. As a result, stream acid neutralizing capacity (ANC) and stream $\mathrm{pH}$ decline. Examination of the effects of regional changes in acidic deposition, using biogeochemical models such as NuCM (Elliott et al., 2008) and MAGIC (Sullivan et al., 2007; Sullivan et al., 2011) found sensitivity to $\mathrm{SO}_{4}$ deposition was

72 related to soils and parent material; soils and parent material with low base cations concentrations were particularly sensitive to $\mathrm{SO}_{4}$ deposition.

Base cation depletion in southern Appalachian high elevation watersheds is indicated by 75 stream ANC values below $50 \mu \mathrm{eq} \mathrm{L}^{-1}$, a value that has been defined as acidic (Bulger et al., 76 2000; Sullivan et al., 2007). Sullivan et al. (2008) examined the possibility of ANC recovery in 77 Shenandoah National Park, Virginia US and found that watersheds located on siliciclastic 78 bedrock would require a 77\% decrease in atmospheric $\mathrm{SO}_{4}$ deposition, compared to 1990 levels, 79 to reach an ANC level of $50 \mu \mathrm{eq} \mathrm{L}^{-1}$ due to low concentrations of base cations in the soil. 
Sullivan et al. (2011) used the biogeochemical cycling model MAGIC and data from 65 acid

81

82

83

84

85

86

87

88 sensitive watersheds in eastern Tennessee and western North Carolina to back cast historical ANC values; they estimated that in 1860 , ANC was as low as $30 \mu \mathrm{eq} \mathrm{L}^{-1}$ with a median of 65 $\mu$ eq $\mathrm{L}^{-1}$. Likens et al. (1996) estimated that pre-industrial revolution stream ANC in the Northeastern US averaged $20 \mu \mathrm{eq} \mathrm{L}^{-1}$. While stream chemistry at Hubbard Brook Experimental Forest has shown consistent improvement (declining $\mathrm{SO}_{4}$, increasing $\mathrm{pH}$ and $\mathrm{ANC}$ ) since the implementation of the Clean Air Act in 1970, stream ANC values remain low. Likens and Buso (2012) concluded that soil weathering processes have not been rapid enough to replenish stream Ca concentrations, leaving diluted streams with altered cation ratios. Soils in the southern Appalachians have high $\mathrm{SO}_{4}$ retention capacity, which may delay the recovery of stream base cations. Rice et al. (2014) predicted that soils at three locations in western North Carolina will crossover from retaining to releasing $\mathrm{SO}_{4}$ between 2023 and 2025.

Liming is a potential management option to restore streams and forest soils by decreasing acidity and increasing base cation availability. Lime is routinely used in agricultural systems, increasing soil $\mathrm{pH}$, as well as $\mathrm{Ca}$ and $\mathrm{Mg}$ availability while also reducing Al solubility. Lime contains $\mathrm{Ca}$ and $\mathrm{Mg}$, the two major divalent base cations; the ratio of these cations is dependent on the lime sources. Huettl (1993) and more recently Reid and Watmough (2014) review benefits and problems of lime applications in forest liming studies. The meta-analysis conducted by Reid and Watmough (2014) found that 67\% of lime treatment trials showed increased soil pH and foliar Ca concentration. Soil $\mathrm{pH}$ response was greater in organic compared to mineral soils and Ca foliar response was positively correlated with treatment dose. Huettl (1993) focused on historic liming studies in Germany with reported benefits including increased soil $\mathrm{Ca}$ and $\mathrm{Mg}$ in O-horizons and surface mineral soils, which was accompanied by increased soil cation exchange 
103 capacity (CEC) and percent base saturation (\%BS). Conversely, there was also evidence of 104 increased soil $\mathrm{NO}_{3}$ production following liming that resulted in cation leaching from subsoils.

105 Increased rates of nitrification following liming were also found in forested sites in Finland

106 (Priha and Smolander, 1995) and was stated as a concern because of the potential for accelerated

107 cation leaching losses. Elliott et al. (2013) measured the response of soil and soil solution to

108 liming following a wildfire in the Linville Gorge Wilderness Area in western North Carolina, a

109 site previously shown to have low soil cation availability and acidic streams (Elliott et al., 2008).

110 They found significant increases in surface mineral soil ECEC, $\mathrm{pH}$, and $\mathrm{Ca}$ and a decline in $\mathrm{Al}$ as

111 well as increases in soil solution $\mathrm{NO}_{3}$. However, the lime response was short-lived, which they

112 attributed to the small amount of lime added to the site $\left(1.1 \mathrm{Mg} \mathrm{ha}^{-1}\right)$. In other forest liming

113 studies, the effects of liming in the O-horizon and surface mineral soils were long-term, up to 21

114 years (Long et al., 2015), and in some cases resulted in the accumulation of organic material in

115 the O-horizon (Johnson et al., 1995).

The continued sensitivity of southern Appalachian streams to atmospheric deposition

117 emphasizes the need to identify watershed characteristics that influence stream chemistry

118 responses to acidic deposition. For example, McDonnell et al. (2014) developed a screening tool

119 that used a mass balance model to estimate critical loads for watersheds at risk of acidification

120 based on $\mathrm{S}$ deposition. Although coarsely modeled at the regional scale, their work suggested

121 that catchment characteristics could be used to identify catchments at risk and help managers

122 prioritize stream monitoring and restoration efforts through liming. Hence, our first objective

123 was to identify catchment biotic, physical and chemical characteristics, that are potential indices

124 of stream acidity measured as $\mathrm{ANC}, \mathrm{pH}$, or $\mathrm{Ca}: \mathrm{Al}$ molar ratio. A better understanding of these

125 catchment scale characteristics and their relationship with stream chemistry could be used to 
126 evaluate restoration options such as liming. Our second objective was to estimate catchment

127 lime requirements and consider how liming may improve stream chemistry.

To address these objectives we studied three large watersheds in the southern

129 Appalachian Mountains along a gradient of acidic deposition with differing geology. Within

130 each watershed we selected first order catchments that represented a range of elevations (849-

$1311526 \mathrm{~m}$ ) and stream ANC values based on previous studies (W.A Jackson, unpublished data).

132 We characterized all catchments in terms of overstory tree species composition and stand

133 characteristics, site and soil morphology and chemistry, and soil lime requirement. Stream, O-

134 horizon, and mineral soils, were intensively sampled four times over one year to capture seasonal

135 variability in stream chemistry and soil/stream connectivity (Swank and Vose, 1997; McHale et

136 al., 2002).

137

138 2. Materials and Methods

139

140 2.1. Site selection

141

142 Study watersheds were selected based on the following criteria: a) they exceeded critical loads of

143 acidic deposition (McNulty et al., 2007; McDonnell et al., 2014), b) they were included in a

144 USDA Forest Service, regional synoptic sampling effort to identify streams in $1^{\text {st }}$ order

145 catchments with low ANC (W. A Jackson, unpublished). The three watersheds are from west to

146 east, North River (NR, 35 latitude, $84^{\circ}$ longitude; Cherokee National Forest, Tennessee),

147 Santeetlah Creek (SC, $35^{\circ}$ latitude, $84^{\circ}$ longitude; Nantahala National Forest, North Carolina),

148 and the North Fork of the French Broad (FB, $35^{\circ}$ latitude, $82^{\circ}$ longitude; Pisgah National Forest, 
149 North Carolina) (Fig. 1). Watershed size ranged from 4800 ha at NR to 9800 ha at FB; between $15017 \%(\mathrm{NR})$ and $53 \%(\mathrm{SC})$ of the watershed area was above $1000 \mathrm{~m}$ in elevation. All watersheds 151 contained numerous $1^{\text {st }}$ order catchments with a range of median ANC values classified as, not 152 acidic $\left(\right.$ ANC $>50 \mu$ eq L $\left.\mathrm{L}^{-1}\right)$, intermediate $\left(\mathrm{ANC}=20-50 \mu \mathrm{eq} \mathrm{L}^{-1}\right)$, episodically acidic $(\mathrm{ANC}=0$

$15320 \mu \mathrm{eq} \mathrm{L} \mathrm{L}^{-1}$ ), and chronically acidic (ANC $\left.<0 \mu \mathrm{eq} \mathrm{L} \mathrm{L}^{-1}\right)($ Bulger et al., 2000). In late 2011, we selected 4-6 first order catchments within each watershed that 155 represented the range in elevation and stream ANC described above. The stream collection 156 location for all catchments was greater than $850 \mathrm{~m}$ in elevation; 5 catchments in NR, 4 157 catchments in $\mathrm{SC}$, and 6 catchments in $\mathrm{FB}(\mathrm{N}=15$ catchments). Within each catchment we 158 established two-10 $\mathrm{m}$ diameter circular sample plots, one in the riparian zone and one on the 159 hillslope. The center of the riparian plot was $6 \mathrm{~m}$ from the stream and the hillslope plot was ca. $16040 \mathrm{~m}$ upslope from the riparian plot, where soil morphology and vegetative composition was 161 different than the riparian zone. The total number of plots per watershed were, $N R, n=10 ; S C n$ $162=8 ; \mathrm{FB}, \mathrm{n}=12 ;$ a total of 30 plots. Seasonal stream, O-horizon and mineral soil sample 163 collection began in May 2012. Table 1 contains a list of all measurements divided into 164 catchment, catchment geochemical, soil O-horizon, mineral soil and stream chemistry variables.

\subsection{Catchment characterization}

167

168 We collected several types of data from all riparian and hillslope plots to characterize each 169 catchment. Plot measurements included mineral soil morphology (A horizon depth, total profile 170 depth to saprolite or bedrock), O-horizon morphology (Oi and Oe+Oa weight, Oe+Oa depth), 171 plot morphology (elevation, slope, aspect), and vegetation characteristics. From the center point 
172 of each plot, overstory vegetation characteristics were obtained using a variable radius plot 173 sampling method with a wedge prism (2.0 BAF, metric), and tree diameters within the variable

174 plot were measured at breast height (DBH at $1.37 \mathrm{~m}$ aboveground) to calculate species-specific

175 basal area and species composition. We measured tree height, using a clinometer, of the six 176 dominant or co-dominant trees within the variable radius plot.

\subsection{Stream sample collection and analysis}

To capture seasonal variation, stream samples were collected from each catchment in early summer (May 2012), mid-summer (Jul/Aug 2012), fall (Nov 2012), and spring (Apr 2013) a total of four collections; all sample collections were conducted while streams were at baseflow levels. For each date, we collected stream water grab samples in each catchment adjacent to 184 riparian plots ( $\mathrm{n}=4,5$ or 6 catchment samples per watershed per date). Water samples were collected in three bottles, one sample bottle was filtered in the field $(<0.70 \mu \mathrm{m}$ pre-muffled glass fiber filter), and all were stored in a cooler, then placed in a refrigerator $\left(4^{\circ} \mathrm{C}\right)$ or a freezer until analyses were conducted using standard laboratory procedures (Miniat et al., 2014). Solution $\mathrm{pH}$ was determined on an unfrozen unfiltered sample within 24 hours of collection using an Orion

189 Research digital $\mathrm{pH}$ meter 611 with a Broadley James $\mathrm{pH}$ probe. Cation concentrations $(\mathrm{Ca}, \mathrm{Mg}$, $190 \mathrm{Na}, \mathrm{K}$, and $\mathrm{Al}$ ) were determined on previously frozen unfiltered samples using an inductively 191 coupled plasma spectrometer (ICP) (Thermo Fisher iCAP 6300, Thermo Fisher Scientific, 192 Madison WI). Stream Ca:Al molar ratios were calculated as $\mathrm{mmol} \mathrm{L}^{-1}$. Anion concentrations $193\left(\mathrm{NO}_{3}, \mathrm{SO}_{4}\right.$, and $\left.\mathrm{Cl}\right)$, were determined on previously frozen unfiltered samples using a Dionex 194 ICS 4000 Capillary Ion Chromatograph (Thermo Fisher Scientific, Madison WI). Dissolved 
195 organic carbon (DOC) and total dissolved nitrogen (TDN) analysis was determined on filtered 196 previously frozen sample on a Shimadzu TOC-VCPH TNM-1 (Shimadzu Scientific Instruments, 197 Columbia, MD). Cation and anion concentrations are reported as $\mu$ eq $\mathrm{L}^{-1}$ and DOC and TDN are 198 reported as $\mathrm{mg} \mathrm{L}^{-1}$. Stream acid neutralizing capacity (ANC) was calculated as:

$\operatorname{ANC}\left(\mu\right.$ eq $\left.L^{-1}\right)=\sum$ base cations $(\mathrm{Ca}+\mathrm{Mg}+\mathrm{Na}+\mathrm{K})-\sum$ acid anions $\left(\mathrm{SO}_{4}+\mathrm{NO}_{3}+\mathrm{Cl}\right)$

\subsection{Soil O-horizon sampling and analysis}

203

Soil O-horizon samples were collected using a 30 x $30 \mathrm{~cm}\left(0.09 \mathrm{~m}^{2}\right)$ frame $(3$ sample frames per plot) at random distances and directions from the plot center for each collection date; collection dates coincided with stream sampling dates (i.e., early summer (May 2012), mid-summer (Jul/Aug 2012), fall (Nov 2012), and spring (Apr 2013)). The O-horizon was separated into Oi and $\mathrm{Oe}+\mathrm{Oa}$ horizons in the field, and each horizon from each location was placed in a paper bag sample collection was conducted soon after leaf-fall from all watersheds and we used the Oi horizon chemistry data as a proxy for litterfall and an index of soil nutrient availability, a

212 geochemical characteristic. Depth of the Oa+Oe horizon was measured along the edge of each 213 sample frame and recorded. Upon returning to the laboratory, all samples were oven dried at 60

$214{ }^{\circ} \mathrm{C}$ until reaching a constant weight; samples were weighed to the nearest $0.01 \mathrm{~g}$. Dried samples 215 were thoroughly mixed, composited by plot and horizon, ground to $<1 \mathrm{~mm}$ using a Retsch

216 grinding mill (Retsch, Inc., Newtown, PA), mixed again, and a subsample was placed in a glass 217 vial for storage prior to analysis. Samples were analyzed for total $\mathrm{C}$ and $\mathrm{N}$ by combustion on a 
Flash EA 1112 series (CE Elantech, Lakewood, NJ). Total phosphorus (P) and cation (Ca, Mg, $\mathrm{Na}, \mathrm{K}$, and $\mathrm{Al}$ ) concentrations were determined by dry-ashing a $0.5 \mathrm{~g}$ sample at $500^{\circ} \mathrm{C}$ for $4 \mathrm{hrs}$. followed by digestion in 2.2 M nitric acid (Miniat et al., 2014), the resulting solution was analyzed using ICP as described above. Ash-free dry weight of all O-horizon samples was measured during the dry-ashing/digestion process to allow sample weight correction for mineral soil contamination. All weight and nutrient concentration data presented for Oe+Oa horizon samples are presented on an ash-free basis. Oi horizon samples contained less than 5\% mineral material, data are presented on an oven-dry weight basis.

\subsection{Mineral soil sampling and analysis}

Composite mineral soil samples were collected using a $2.5 \mathrm{~cm}$ diameter soil probe from each plot by depth (surface soil, $0-10 \mathrm{~cm}$; subsoil, 10-30 cm; and deep soil, $30+\mathrm{cm}$ ), for each date as described above (i.e., early summer (May 2012), mid-summer (Jul/Aug 2012), fall (Nov 2012), and spring (Apr 2013)). Composite samples consisted of 12-20 individual soil cores from random locations within each 10-m circular plot. Total profile depth to saprolite reached at each location sampled was recorded; a total of 360 soil samples were collected ( 30 plots $x 3$ soil depths $\mathrm{x} 4$ dates). Mineral soil samples were placed in re-sealable plastic bags, returned to the lab, air dried to a constant weight, sieved to $<2 \mathrm{~mm}$ and stored in a $120 \mathrm{ml}$ glass jar for storage prior to chemical analysis. Soil $\mathrm{pH}$ was determined in a $1: 1$ soil to $0.01 \mathrm{M} \mathrm{CaCl}_{2}$ slurry with a Thermoscientific Orion 3 star $\mathrm{pH}$ bench-top meter with a Thermo Scientific Orion $\mathrm{pH}$ probe. We determined exchangeable cation concentrations $(\mathrm{Ca}, \mathrm{Mg}, \mathrm{Na}, \mathrm{K}$, and $\mathrm{Al})$ as well as effective cation exchange capacity (ECEC) by extracting cations from $5.0 \mathrm{~g}$ of soil with $50 \mathrm{ml} 1.0 \mathrm{M}$ 
$241 \mathrm{NH}_{4} \mathrm{Cl}$ on a mechanical vacuum extractor (SampleTek, Science Hill, KY), followed by rinsing

242 the soil with $95 \%$ EtOH and extraction of remaining $\mathrm{NH}_{4}$ with $1 \mathrm{M} \mathrm{KCl}$ to determine ECEC.

243 Cation concentrations in $\mathrm{NH}_{4} \mathrm{Cl}$ solution were determined using ICP as described above; $\mathrm{NH}_{4}$

244 concentration in $\mathrm{KCl}$ extraction solution was determined colorimetrically using the alkaline

245 phenol method (USEPA, 1983), and used to calculate ECEC ( $\mathrm{cmol} \mathrm{kg}^{-1}$ ). Percent base saturation

$246(\% \mathrm{BS})$ was calculated: $\% \mathrm{BS}=((\mathrm{Ca}+\mathrm{Mg}+\mathrm{Na}+\mathrm{K}) / \mathrm{ECEC}) * 100$. Ca to Al ratio was

247 calculated using molar concentrations $\left(\mathrm{Ca}: \mathrm{Al} \mathrm{mmol} \mathrm{kg}{ }^{-1}\right)$. Extractable phosphate $\left(\mathrm{PO}_{4}\right)$ was

248 determined by extracting $5.0 \mathrm{~g}$ of soil in $20 \mathrm{ml}$ dilute double acid $(0.05 \mathrm{M} \mathrm{HCl}+0.0125 \mathrm{M}$

$249 \mathrm{H}_{2} \mathrm{SO}_{4}$ ) followed by centrifugation and determination of $\mathrm{PO}_{4}$ in solution by ICP as described

250 above (Kuo, 1996; Miniat et al., 2014). Sub-samples ( $5 \mathrm{~g})$ of each soil sample were ground to

251 a fine powder prior to total $\mathrm{C}$ and $\mathrm{N}$ analysis by combustion as described above.

252 We conducted total elemental analysis of soils from each watershed, catchment, plot, and

253 depth collected in April 2012 using the closed vessel aqua regia and hydrofluoric acid dissolution

254 method (Hossner, 1996) followed by analysis with ICP as described above on soils as a proxy for

255 total mineral availability and soil parent material as geochemical characteristics. We calculated

256 an indicator of the ratio of felsic to mafic parent material (Felsic:Mafic) as $\mathrm{K}+\mathrm{Na}: \mathrm{Ca}+\mathrm{Mg}$.

257 Felsic parent materials are dominated by $\mathrm{K}$ and $\mathrm{Na}$ (monovalent ions) and Mafic parent materials

258 by $\mathrm{Ca}$ and $\mathrm{Mg}$ (divalent ions). We also calculated the $\mathrm{Fe}: \mathrm{Al}$ ratio as an indicator of the

259 mineralogy of the soils clay component, which regulates the soil cation exchange capacity. We

260 used recent soil surveys for catchment within watershed descriptions including soil bulk density

261 and percent coarse fragment of each soil type by depth (Soil_Survey_Staff, 2014); these values

262 were used with laboratory determined soil chemistry (extractable and total elemental cations) to 
263 calculate total available and total mineral nutrient content of the soil profile $\left(\mathrm{kg} \mathrm{ha}^{-1}\right)$ for each 264 plot within each catchment.

\subsection{Catchment Lime Requirement}

267

268 To estimate the lime requirement for each catchment, we analyzed mineral soils collected at all 269 four dates, from all plots, catchments, and watersheds (3 depths x 4 dates x 2 plots x 15 270 catchments $=360$ samples). We used the Mehlich Single Buffer method (Sims, 1996), to 271 estimate lime addition required to adjust the mineral soil to $\mathrm{pH}$ to 5.5. This method yields lime 272 application estimates in $\mathrm{Mg} \mathrm{ha}^{-1}$ of $\mathrm{CaCO}_{3}$ assuming a $20 \mathrm{~cm}$ soil depth. We estimated the lime 273 required to adjust the surface mineral soil $(0-10 \mathrm{~cm})$, dividing the estimated lime requirement by

2742 (Lime Required $0-10 \mathrm{~cm}=$ Lime $\mathrm{Mg} \mathrm{ha}^{-1} / 2$ ). We calculated the sum of the surface and subsoil 275 mineral soil depths by summing the lime requirement for each depth (Lime Required $0-30 \mathrm{~cm}=$ 276 Lime Required 0-10 cm + Lime Required 10-30 cm).

278 2.7. Statistical Analysis

280 Our statistical analysis varied depending on whether we were testing for spatial vs. temporal 281 differences in variables. For variables sampled by date (i.e., stream chemistry, mineral soil 282 chemistry and O-horizon chemistry) sample date was included as a discrete qualitative repeated 283 measures factor because we did not expect a trend over time that could be modeled with a 284 mathematical function (Littell, 2007). We tested several covariance structures for each dataset as 285 suggested by Littell et al. (1998; 2007), including compound symmetry (CS), Huynh-Feldt (HF), 
spatial power structure (SP(POW)), variance components ( $\mathrm{VC})$ and others, selecting the covariance structure that resulted in the minimum corrected Akaike's Information Criterion (AICC) value (Hurvich and Tsai, 1991). We examined watershed, sample collection date, and watershed by date interaction effects on stream chemistry variables using a nested plot experimental design with watershed and date (fixed effects) and catchment nested within watersheds (random effect) using Proc Mixed (SAS v9.3 (SAS, 2013)). We included sample date in a repeated measures statement, using compound symmetry (CS) as the covariance structure. A nested split-plot experimental design was used to examine watershed and date effects on O-horizon and mineral soil chemistry data with watershed (fixed effect), date (fixed effect), catchment nested within watershed (random effect), and slope position as a split plot within watersheds (fixed effect) using Proc Mixed (SAS, 2013). We included sample date in a repeated measures statement using Huynh-Feldt (HF) covariance structure for O-horizon chemistry and a spatial power structure (SP(POW)) for mineral soil chemistry. O-horizon and soil depths were analyzed separately. For testing spatial differences in variables (i.e., among and within watersheds and catchments), we used a nested split-plot experimental design, examining watershed effects (fixed effect), catchment within watershed effect (random) and the split-plot of slope position (i.e., midslope vs. riparian) within catchment (fixed) using Proc Mixed (SAS, 2013); we used variance components (VC) covariance structure.

We used Proc Mixed (SAS, 2013) to select catchment characteristics, O-horizon chemistry, mineral soil chemistry and catchment chemical characteristic variables that were significant in informing the best statistical model of stream chemistry variables (ANC, $\mathrm{pH}$, and Ca:Al molar ratio). For these analyses, we used mean catchment values (i.e., average of the hillslope and riparian plots) for catchment characteristics, O-horizon chemistry, mineral soil 
309 chemistry and catchment chemistry as the independent variables. We also examined the

310 influence of the riparian zone by examining riparian plot data separately. First, we conducted

311 linear regression analysis (Proc Reg (SAS, 2013)) for each data set (catchment characteristics, O-

312 horizon, soil chemistry, and catchment chemical characteristics), to reduce the number of

313 variables included in the analysis. Regression analyses included comparison of the same

314 measurements made in different O-horizons and mineral soil depths. Variables that did not

315 exhibit significant collinearity $\left(r^{2}\right.$-value $\left.<0.70\right)$ were used in the first step of model analysis. We

316 also included variables (i.e., extractable Ca:Al molar ratio, ratio of cation concentrations in

317 surface mineral soil relative to deep soil) that utilized several measurements and were potentially

318 useful as explanatory variables. Next, variables from each data set were included as covariates

319 in the mixed model analysis; variables were eliminated if the probability $(P)$ of an $F$-value was

320 greater than 0.25 ; the result yielded 2-8 variables for final testing. We included all of these

321 variables (those with $P<0.25$ ) to select the final model which included only variables with $P \leqq$

322 0.05. By examining datasets separately we were able to identify the best statistical model and

323 significant covariates for stream chemistry. We used the nested experimental design with

324 repeated measures to identify O-horizon and mineral soil chemistry variables that were

325 significant covariates of stream chemistry. We used the mean stream chemistry data (four

326 sample collection dates), in the nested split-plot experimental design to develop the best

327 statistical model for catchment characteristic data, both non-chemical and chemical. The results

328 presented are primarily the variables that were identified as significant covariates in the

329 statistical models examining variation in stream chemistry (Results section 3.6). 


\subsection{Watershed and catchment characterization}

The catchments and plots within watersheds represented a broad range of morphological and vegetative characteristics. Soil A-horizon depth ranged from 5 to $33 \mathrm{~cm}$ and total soil profile

337 depth ranged from $43 \mathrm{~cm}$ to $92 \mathrm{~cm}$ (Fig. 2). Overstory basal area ranged from $14 \mathrm{~m}^{2} \mathrm{ha}^{-1}$ to 56

$338 \mathrm{~m}^{2} \mathrm{ha}^{-1}$ and mean plot tree height ranged from $18.5 \mathrm{~m}$ to $54.1 \mathrm{~m}$ (Fig. 2). Basal area of Quercus 339 spp. ranged from 0-22 $\mathrm{m}^{2} \mathrm{ha}^{-1}$, and Acer spp. ranged from 0-14 $\mathrm{m}^{2} \mathrm{ha}^{-1}$ (Fig. 2). Basal area of 340 Quercus spp. varied with slope position $(F=12.58 ; P<0.01)$ with greater Quercus spp. present 341 in the hillslope position.

\subsection{Variation in O-horizon mass and chemistry}

Watershed did not have a significant effect on Oi horizon mass, total $\mathrm{C}$ or total $\mathrm{N}$ concentrations

346 however, date effect and date by watershed interaction were significant. As expected, the

347 greatest Oi horizon mass was measured in fall (Nov) and the least in summer (Jul). Ca and Al concentrations differed significantly among watersheds $(\mathrm{Ca}, F=3.83, P=0.04 ; \mathrm{Al}, F=3.47, P$

$349=0.05)$ and sample collection date $(\mathrm{Ca}, F=4.75, P<0.01 ; \mathrm{Al}, F=5.39, P<0.01)$. Neither 350 slope position nor watershed by date interaction were significant.

Oe+Oa horizon mass was significantly affected by watershed $(F=16.17, P<0.001)$ and 352 date $(F=8.94, P<0.001)$. Mass was greatest in the spring (Apr 2013); watershed by date interaction was not significant. Collection date had a significant effect on total $\mathrm{C}$ and $\mathrm{N}$

354 concentration $(\mathrm{C}, F=3.35, P=0.02 ; \mathrm{N}, F=3.36, P=0.02)$. Oe+Oa horizon $\mathrm{Ca}$ concentrations 
355 ranged from $0.89-5.0 \mathrm{~g} \mathrm{Ca} \mathrm{kg}^{-1}$ and differed among watersheds $(F=9.39, P=0.001)$ and by date

$356(F=7.84, P=0.001)$; there were no significant watershed by date interactions. Oe+Oa Al

357 concentrations did not differ among watersheds but date effect was significant $(F=4.25, P=$

$3580.01)$.

359

360

\subsection{Variation in mineral soil chemistry}

361

362

Mineral soil chemical characteristics in the surface soil depth varied significantly with both

363

watershed and sample date; watershed by date interaction were significant for some variables

364

365

(soil $\mathrm{pH}$, total $\mathrm{N}$ and total $\mathrm{C}$ ). Soil $\mathrm{pH}$ ranged from 3.1-4.4 (watershed, $F=6.24, P=0.01$; date, $F=15.18, P<0.001$ ) and $\%$ BS ranged from $2.3-42.2 \mathrm{cmol}_{\mathrm{c}} \mathrm{kg}^{-1}$ (watershed, $F=7.51, P<0.01$;

366 date, $F=6.02, P<0.01$ ). Total $\mathrm{C}$ ranged from $10.9-153.2 \mathrm{~g} \mathrm{~kg}^{-1}$ (watershed, $F=28.44, P<$

3670.01 ; date, $F=5.04, P<0.01$ ) and total $\mathrm{N}$ from $0.63-10.3 \mathrm{~g} \mathrm{~kg}^{-1}$ (watershed, $F=22.60, P<$ 3680.01 ; date, $F=5.28, P<0.01)$.

Deep mineral soil $\mathrm{pH}, \% \mathrm{BS}$, total $\mathrm{N}$ and total $\mathrm{C}$ concentrations showed a significant

370

371

372

373

374 $375<0.01)$.

376

377 watershed and date effect; watershed by date interaction was significant for $\mathrm{pH}$, total $\mathrm{N}$ and total

C. Soil pH ranged from 4.1-4.7 (watershed, $F=5.33, P=0.01$; date, $F=3.30, P=0.03$ ) and

\%BS ranged from 1.2-14.7 $\mathrm{cmol}_{\mathrm{c}} \mathrm{kg}^{-1}$ (watershed, $F=7.49, P<0.01$; date, $F=11.00, P<0.01$ ).

Deep mineral soil total $\mathrm{C}$ ranged from $6.5-114.5 \mathrm{~g} \mathrm{~kg}^{-1}$ (watershed, $F=7.70, P<0.01$; date, $F=$

4.14, $P<0.01$ ) and total $\mathrm{N}$ from $0.51-7.4 \mathrm{~g} \mathrm{~kg}^{-1}$ (watershed, $F=9.92, P<0.01$; date, $F=4.84, P$

Mineral soil total $\mathrm{Ca}, \mathrm{K}$, and $\mathrm{P}$ in all mineral soil depths (surface, 0-10 cm; subsoil, 10$30 \mathrm{~cm}$; deep soil, $30+\mathrm{cm}$ ) differed among watersheds. Surface mineral soil total Ca 
378 concentrations ranged from $157-19900 \mathrm{~g} \mathrm{~kg}^{-1}(F=9.57, P<0.01)$ and total $\mathrm{K}$ concentrations

379 ranged from $6900-24300 \mathrm{~g} \mathrm{~kg}^{-1}(F=8.93, P<0.01)$. The ratio of extractable Ca to total Ca

380 (extractable Ca:total $\mathrm{Ca}$ ) also differed significantly among watersheds $(F=12.46 ; P<0.001)$ as

381 did the Felsic:Mafic ratio $(F=20.86 ; P<0.01)$ and the Fe:Al ratio $(F=8.50 ; P<0.01)$.

382

\subsection{Catchment soil nutrient availability characterization}

384

We used nutrient concentrations in the Nov Oi horizon collection, a time when this horizon 386 closely represents litterfall (hereafter, litterfall), and soil nutrient availability. None of the variables measured, litterfall mass, total $\mathrm{N}, \mathrm{Ca}, \mathrm{Al}$ concentrations, or the $\mathrm{Ca}: \mathrm{Al}$ molar ratio showed significant differences among watersheds. Plot slope position had a significant effect on litterfall total Ca concentration $(F=7.79, P=0.02)$.

\subsection{Watershed variation in stream chemistry}

Stream ANC varied significantly among watersheds; ANC values ranged from $6 \mu \mathrm{eq} \mathrm{L}^{-1}$ to 84

$394 \mu$ eq $\mathrm{L}^{-1}$ at NR, from $-5 \mu$ eq $\mathrm{L}^{-1}$ to $42 \mu$ eq $\mathrm{L}^{-1}$ at $\mathrm{SC}$, and $-7 \mu$ eq $\mathrm{L}^{-1}$ to $51 \mu$ eq $\mathrm{L}^{-1}$ at FB, (Table 2

395 and Fig. 3). Sample collection date had no significant effect on stream ANC. Stream pH did not 396 vary among watersheds or sample dates (Table 2). Mean stream $\mathrm{pH}$ values ranged from 6.1-6.7 397 in NR, from 5.4-6.3 in SC, and 5.8-6.4 in FB (Fig. 3). Watershed and date had a significant 398 effect on stream Ca:Al molar ratio; there was no watershed by date interaction (Table 2). Stream $399 \mathrm{Ca}$ :Al molar ratio was lower in the summer compared to fall and spring. 
Nested split-plot analyses of biotic and physical catchment characteristics identified stream

404 elevation $(P=0.02)$ as the only significant covariate for stream ANC (Table 3 and Fig. 4); basal area of Quercus spp. was a marginally positive covariate $(P=0.08)$. Biotic and physical

406 characteristics that were significant in covariates in analysis of stream $\mathrm{pH}$ were depth of mineral 407 soil A horizon $(P=0.001)$ and total catchment basal area $(P=0.01)$, both with positive 408 coefficients (Table 3 and Fig. 4). Vegetation characteristics were also significant covariates for 409 coefficient (Table 3 and Fig. 3).

Nested split-plot analysis of catchment chemical characteristics identified total soil $\mathrm{Ca}$ 412 content $\left(\mathrm{kg} \mathrm{ha}^{-1}\right)(P<0.001)$, as a significant negative covariate for stream ANC (Table 3 and 413 Fig. 5). The extractable Ca:total $\mathrm{Ca}$ in the surface soil $(P=0.02)$ was the only significant 414 catchment chemical characteristic (positive coefficient) that varied with stream pH (Table 3 and 415 Fig. 5). Analysis of stream Ca:Al molar ratio identified two significant covariates, surface soil 416 Fe:Al ratio $(P=0.01)$ and litterfall $\mathrm{Ca}$ :Al ratio $(P=0.02)$, both had negative coefficients (Table 4173 and Fig. 5).

418 O-horizon physical and chemical characteristics were included in repeated measures 419 analysis of stream chemistry variability. Stream ANC analyses identified total N concentration 420 (negative coefficient) in the $\mathrm{Oe}+\mathrm{Oa}$ horizon as a significant covariate $(P=0.05)$. Oi horizon 421 mass $\left(\mathrm{g} \mathrm{m}^{-2}\right)$ was a significant covariate in stream $\mathrm{pH}$ analysis $(P=0.001)$ with a negative 422 coefficient (Table 3 and Fig. 6). Al concentration in the Oi horizon $(P=0.01)$ was a positive 423 covariate for stream Ca:Al molar ratio (Table 3 and Fig. 6). 
Repeated measures analysis of soil chemical characteristics identified two significant

425

426

427

428

429

430

431

432

433

434

435

436

437

438

439

440

441

442

443

444

445

446

covariates for stream ANC, deep mineral soil total $\mathrm{C}$ concentration $(P<0.001)$ and surface mineral soil Al concentration $(P=0.02)$; both had negative coefficients (Table 3 and Fig. 7).

Deep mineral soil total $\mathrm{C}$ concentration $(P=0.002)$ was also identified as a significant covariate in stream $\mathrm{pH}$ analysis. Analysis of stream $\mathrm{Ca}$ :Al molar ratio identified subsoil $(30+\mathrm{cm}) \% \mathrm{BS}(P$ $=0.05)$ as a significant covariate with a positive coefficient (Table 3 and Fig. 7).

We also examined the effect of only the riparian plot measurements of non-chemical, Ohorizon physical and chemical, and soil physical and chemical characteristics on stream chemistry (Table 4$)$. Nested split plot analysis identified stream elevation $(P=0.02)$ as a significant covariate with stream ANC (Table 4), and A horizon depth as a significant covariate for both $\mathrm{pH}(P<0.001)$ and $\mathrm{Ca}$ :Al molar ratio $(\mathrm{P}<0.01)$. Analysis of stream $\mathrm{pH}$ with riparian plot chemical characteristics included the Felsic:Mafic ratio of the deep mineral soil $(P<0.001)$ as well as extractable $\mathrm{K}$ :total $\mathrm{K}(P=0.001)$ and surface soil total Ca concentration $(P=0.001)$ as significant covariates. Both Felsic:Mafic and extractable K:total K had positive coefficients while total surface soil Ca was negative (Table 4). There were no significant soil chemistry covariates in the riparian plot analysis of stream $\mathrm{Ca}$ :Al molar ratio. Repeated measures analysis of stream chemistry and riparian plot O-horizon chemistry identified no significant covariates for stream ANC or $\mathrm{pH}$, whereas $\mathrm{Al}$ concentration of the Oi horizon $(P<0.01)$ and $\mathrm{C}: \mathrm{N}$ of the Oe+Oa horizon $(P=0.02)$ were significant positive covariates for stream $\mathrm{Ca}$ :Al molar ratio.

Deep mineral soil total $\mathrm{C}$ concentration was a significant soil chemistry characteristic, providing a negative coefficient for $\mathrm{ANC}(P<0.001)$ and a positive coefficient for stream $\mathrm{pH}(P=0.01)$ analyses. 
449 We conducted laboratory analyses to estimate the lime application required to increase soil to $\mathrm{pH}$ 4505.5 for each soil layer (Fig. 8). Watershed did not have a significant effect on lime requirement; 451 however, slope position was significant for both surface mineral soil $(0-10 \mathrm{~cm})(F=13.72, P<$ $4520.001)$ and mineral soil $0-30 \mathrm{~cm}(F=8.46, P=0.005)$, hillslope plots required greater lime 453 inputs to reach the $\mathrm{pH} 5.5$ target than riparian plots. Lime required to increase the soil to $\mathrm{pH}=$ 4545.5 varied among catchments, ranging from $5.2 \mathrm{Mg} \mathrm{ha}^{-1}$ to $9.5 \mathrm{Mg} \mathrm{ha}^{-1}$ for the surface mineral 455 soil (Fig. 8) and $11.6 \mathrm{Mg} \mathrm{ha}^{-1}$ to $21.1 \mathrm{Mg} \mathrm{ha}^{-1}$ for the surface soil mineral plus subsoil (Fig. 8).

456 Lime requirement was initially included in statistical analyses as a catchment chemical

457 characteristic, but was not identified as a significant covariate for any of the stream chemistry 458 variables.

\section{Discussion}

462 Despite a $40 \%$ decrease in wet $\mathrm{SO}_{4}$ deposition across the eastern United States high elevation

463 streams in the southern Appalachian have been identified as acidic with ANC values $<50 \mu$ eq $\mathrm{L}^{-1}$ 464 (NADP, 2007; Burns et al., 2011). We measured catchment biotic, physical, and chemical 465 characteristics that were potential indicators of stream chemistry. The catchments represented a 466 broad range of all characteristics allowing us to evaluate potential indicators of stream acidity 467 and to help identify catchments where stream acidity could be mitigated with liming. The 468 relationships between indicators and stream chemistry were complex and in some cases opposite 469 of the expected patterns. For example, stream ANC was negatively correlated with total soil Ca, 
470 and stream Ca:Al was negatively correlated with litterfall Ca:Al. These unexpected patterns may

471 be partially due to insufficient sample size (either too few catchments or too few plots within a

472 catchment to capture the full range of variation), seasonally varying patterns of stream/soil

473 connectivity, or as yet undescribed patterns of stream and soil recovery from acidic deposition

474 (Lawrence et al., 2015). Long-term forest soil sampling efforts in the 1980s and 1990s showed

475 declining exchangeable $\mathrm{Ca}$ and increasing soil acidity linked to forest growth and leaching losses

476 (Johnson et al., 1991; Knoepp and Swank, 1995; Lawrence et al., 1995; Likens et al., 1998).

477 Implementation of the CAA in 1970 resulted in the recovery of stream chemistry in Hubbard

478 Brook Experimental Forest (Likens and Buso, 2012). However, since 2007 streams show a

479 declining trend of both acid anions and base cations resulting in a decline in both stream ANC

480 and stream Ca concentrations. Likens and Buso (2012) suggested that this response was due to

481 changes in the stream ion balance from being historically dominated by $\mathrm{Ca}\left(\mathrm{HCO}_{3}\right)_{2}$, then shifting

482 to $\mathrm{CaSO}_{4}$, and currently toward $\mathrm{NaHCO}_{3}$. In another study, Lawrence et al. (2015) examined

483 soil recovery in 27 sites across the NE USA and eastern Canada by resampling soils after 8-24

484 years. They found that site specific decline in $\mathrm{SO}_{4}$ deposition was correlated with increased base

485 saturation and decreased exchangeable $\mathrm{Al}$ in the O-horizon. However, base saturation in B

486 horizon soils had not increased, and actually decreased at 33\% of the sites. These examples of

487 declining soil and stream Ca following reductions in acidic deposition demonstrate the value of

488 long-term stream and soil sampling. Thus, one time collections (or one year of collections) may

489 not reveal all of the interactions between forest growth and nutrient uptake, soil nutrient

490 processes, and stream ion balance, particularly if acidic deposition is expected to continue to

491 decline. 
High elevation catchments in the southern Appalachians are sensitive to acidic deposition not 496 only due to the high rates of input, but also physical factors such as steep topography and soil 497 depth. As expected (Swank and Vose, 1997; Sullivan et al., 2011)(Knoepp, unpublished data), 498 our data show a significant negative linear correlation between stream elevation and measures of 499 stream acidity such as ANC, pH, and Ca:Al molar ratios (Fig. 9); however, we also identified 500 other physical catchment characteristics that could be used to explain variability in stream 501 chemistry. For example, we found significant positive relationships between mineral soil A502 horizon depth and stream $\mathrm{pH}$ and $\mathrm{Ca}: \mathrm{Al}$ molar ratio (Fig 3). The formation and depth of the A503 horizon is the result of vegetation, topography, parent material and other factors of soil formation 504 (Ramann, 1928; Jenny, 1941; Buol et al., 2011); hence, the relationship between soil A-horizon 505 depth and stream chemistry is not surprising due to the movement of organic material, dissolved 506 and exchangeable nutrients, and water through the soil profile. We also expected total soil 507 profile depth would be an indicator of stream chemistry due to its effect on stream/soil 508 connectivity, which directly affects stream chemistry. However, in this study, soil profile depth 509 was not identified as a significant indicator of stream chemistry. Some studies have shown that 510 the movement of chemical constituents to the stream varies with its location in the profile. For 511 example, Lutz et al. (2012) found evidence that $\mathrm{NO}_{3}$ is transported to the stream via subsurface 512 pathways across a range of precipitation event sizes, whereas surface soil DOC is only mobilized 513 when soils become connected with the stream after large precipitation events. Research has also 514 shown that seasonal differences in stream chemistry are often due to differences in hydrologic 515 flow paths and soil/stream connectivity (Christopher et al., 2006; Murdoch and Shanley, 2006a, 
516 b). We conducted our stream collections seasonally to account for the differences in soil/stream 517 connectivity that are evident due to greater stream baseflow in March - May in the southern 518 Appalachians (Swift Jr. et al., 1988).

\subsection{Vegetation parameters}

521

522 The effects of vegetation composition on stream chemistry have been noted in several

523 ecosystems (Knoepp and Swank, 1998; Lovett and Mitchell, 2004; Christopher et al., 2006;

524 Wurzburger and Hendrick, 2007; Knoepp et al., 2008). For example, Christopher et al. (2006)

525 found that the presence of base rich tree species (Acer saccharum Marsh., Tilia americana Mill.,

526 Ostrya virginiana (Mill.) K. Koch) resulted in greater stream $\mathrm{Ca}$ and $\mathrm{NO}_{3}$ concentrations;

527 whereas, concentrations were lower in the watershed dominated by Fagus grandifolia Ehrhart

528 and Pinus strobus L. McLaughlin (2014) found that although hardwood sites contained

529 significantly greater pools of Ca compared to mixed hardwood-conifer sites, they also lost a

530 greater amount of $\mathrm{Ca}$ from the O-horizon and to stream export. In addition, vegetation that

531 stimulates nitrification, resulting in increased soil and soil solution $\mathrm{NO}_{3}$, can also result in

532 increased cation leaching (Lovett and Mitchell, 2004; Christopher et al., 2006). We identified

533 catchment Quercus spp. basal area as a marginally significant covariate in our model of stream

$534 \mathrm{ANC}$ at the catchment scale; where ANC increased with increasing Quercus basal area.

535 Previous work in the southern Appalachians has shown lower $\mathrm{N}$ cycling rates and $\mathrm{N}$ leaching

536 (i.e., lower $\mathrm{NO}_{3}$ in soil solution and lower potential cation leaching) and greater O-horizon

537 accumulation in Quercus dominated sites compared to northern hardwood forests (Knoepp and

538 Swank, 1998; Knoepp et al., 2000; Knoepp et al., 2008). Other significant vegetation 
539 characteristics in our models were mean catchment basal area of all species (positive covariate

540 with stream $\mathrm{pH}$ ) and mean tree height of all species (positive covariate with stream Ca:Al molar

541 ratio). Because catchment basal area is related to site productivity (e.g., nutrient availability and

542 soil $\mathrm{pH}$ ) and species composition (e.g., species specific nutrient uptake and requirements)

543 (Searcy et al., 2003; Hahm et al., 2014), it is not surprising that basal area, tree height, and mean

544 DBH were positively related to stream $\mathrm{pH}$. This suggests that relatively simple forest stand

545 measurements, such as tree heights, diameters, and total basal area, could be useful indicators of

546 sensitive streams (i.e., those with low $\mathrm{Ca}: \mathrm{Al}$ or $\mathrm{pH}$ ). For example, although soil $\mathrm{pH}$ and

547 extractable $\mathrm{Ca}: \mathrm{Al}$ molar ratio were not significant covariates in our stream chemistry models we

548 found significant positive relationships between surface mineral soil $\mathrm{pH}$ and $\mathrm{Ca}: \mathrm{Al}$ molar ratio

549 and mean tree height $\left(r^{2}=0.29, P=0.002\right.$ and $r^{2}=0.18, P=0.02$, respectively $)$ and mean DBH

$550 \quad\left(r^{2}=0.33, P=0.001\right.$ and $r^{2}=0.28, P=0.002$, respectively $)$.

551

552

\subsection{Soil O-horizon and litterfall}

554 Soil O-horizon physical and chemical characteristics were significant covariates in models

555 examining catchment variability in stream chemistry (Table 3 and 4). Past research has

556 examined how overstory litter input and root turnover provide nutrient inputs to unfertilized

557 forest ecosystems (Hursh, 1928; Alban, 1982; Knoepp et al., 2011), and how inputs are affected

558 by site nutrient availability (Knoepp et al., 2000; Ordoñez et al., 2009). In general, O-horizon

559 formation is the result of inputs and turnover rates which are regulated by the interactions among

560 site nutrient availability, temperature, precipitation, and micro- and macrofauna and microbial

561 populations. In some forest ecosystems the Oa-horizon plays an important role in nutrient 
562 availability with many tree roots occupying that layer (Perala and Alban, 1982; Rauland-

563 Rasmussen and Vejre, 1995; Joergensen et al., 2009). The Oa-horizon has been examined as a

564 surrogate for total deposition, as it represents the accumulation of all mineral input sources,

565 litterfall, root turnover, and fungal activity, as well as wet and dry deposition (Weathers et al.,

566 2006; Joergensen et al., 2009). In our study, O-horizon Al concentrations and C:N ratios had a

567 positive relationship with stream $\mathrm{Ca} A \mathrm{Al}$ molar ratio; however, increasing O-horizon total $\mathrm{N}$

568 concentrations resulted in declining stream ANC. This finding is similar to studies examining

569 the declining $\mathrm{SO}_{4}$ deposition. Pannatier et al. (2011) found that $\mathrm{SO}_{4}$ deposition declines in

570 ecosystems where $\mathrm{N}$ deposition was dominant had no effect on improving soil solution

571 chemistry. Lawrence et al. (2012) measured increased exchangeable Al concentrations in B

572 horizon soils in some red spruce forests after years of $\mathrm{SO}_{4}$ decline.

573 We used the Nov Oi horizon collection to represent litterfall chemistry as a proxy for

574 plant available soil nutrients. We found that litterfall $\mathrm{Ca}$ :Al ratio was a significant negative

575 covariate in stream Ca:Al molar ratio. Examination of the relationship between litterfall Ca:Al

576 ratios and soil chemistry and found a weak but positive correlation with soil extractable $\mathrm{Al}\left(r^{2}=\right.$

$5770.18, P=0.02$ ) but not with extractable soil $\mathrm{Ca}$. On the other hand, litterfall Ca concentration

578 was significantly correlated with both soil extractable $\mathrm{Ca}\left(r^{2}=0.35, P=0.001\right)$ and the

579 proportion of extractable Ca (i.e., available to plants) to total elemental $\mathrm{Ca}\left(r^{2}=0.47, P<0.001\right)$.

580 Additionally, seasonally collected Oi-horizon Al concentration was identified as having a

581 positive relationship with stream Ca:Al molar ratio. Halett and Hornbeck (1997) found that soils

582 in both red oak and white pine forests exhibited $\mathrm{Ca}$ depletion while $\mathrm{Al}$ accumulated in the O-

583 horizon. Our data suggest a complex interaction between nutrient availability, plant uptake and

584 litterfall, and O-horizon formation, and ultimately stream Ca:Al molar ratio. Oi-horizon Ca:Al 
585 ratio was greatest in fall (Nov) and least in summer (Jul). As litterfall material transitions from

586 the Oi- to the Oe+Oa- horizon the $\mathrm{Ca}$ Al molar ratio declined 5-fold (Oi horizon $\mathrm{Ca}: \mathrm{Al}=35$,

$587 \mathrm{Oe}+\mathrm{Oa}$ horizon $\mathrm{Ca}: \mathrm{Al}=6$ ) suggesting a preferential loss of $\mathrm{Ca}$ or accumulation of $\mathrm{Al}$ during

588 decomposition and O-horizon formation. The presence of Quercus spp. was positively

589 correlated with ANC, perhaps due to its effect on O-horizon accumulation (Knoepp et al., 2008).

590 Other researchers have documented the linkage between understory vegetation, O-horizon

591 decomposition, and soil nutrient availability (Qiao et al., 2014; Elliott et al., 2015), however, we

592 did not include measurement of leaf litterfall decomposition rates or herbaceous plant surveys in 593 this study.

594

595 4.4. Mineral soil chemistry

596

597 The interaction of soils with soil water and ultimately stream water is determined not only by

598 mineral soil exchangeable chemistry but also by parent material which controls the release of

599 cations and anions through weathering processes (Velbel, 1985; Velbel, 1988). We used mineral

600 soil total elemental cation concentrations $(\mathrm{Ca}, \mathrm{Mg}, \mathrm{K}$ and $\mathrm{Na}$ ) as a proxy for parent material and

601 found that soil total elemental Ca content was negatively related to stream ANC (Table 3) at the

602 catchment scale, while surface soil total $\mathrm{Ca}$ was related to stream $\mathrm{pH}$ within the riparian zone

603 alone (Table 4). Other mineral soil total cation parameters (Fe:Al ratio, Felsic:Mafic, extractable

$604 \mathrm{~K}:$ total $\mathrm{K}$ ), at both the catchment and riparian zone scale, were significantly related to stream $\mathrm{pH}$

605 and $\mathrm{Ca}: \mathrm{Al}$ molar ratio (Table 3 and 4). The role of riparian zone characteristics differs among

606 stream acidity indices, perhaps due to differences in location of exchangeable cations and anions

607 within the soil profile (Fölster et al., 2003; Lutz et al., 2012) or differences among watersheds 
608

609

610

611

612

613

614

615

616

617

618

619

620

621

622

623

624

625

626

627 628

629 630

and catchments (Christopher et al., 2006; Talhelm et al., 2012). Elliott et al. (2008) and Sullivan et al. (2011) modeled sensitivity of wilderness areas in western North Carolina USA to $\mathrm{SO}_{4}$ deposition, they found that sites with soils derived from parent material with low base cation concentrations were more sensitive to $\mathrm{SO}_{4}$ deposition. This agrees with the conclusions of other studies (Rice et al., 2006; Sullivan et al., 2007) that suggest that stream ANC is largely regulated by watershed geology. However, soil parent material and stream chemistry relationships are not always predictable due to variation in the regulation of mineral weathering (Velbel and Price, 2007). For example, Grieve (1999) tested the response of mineral soils from three different parent materials (basalt, sandstone sediments, and metamorphosed schists) to leaching with an acidic solution in laboratory experiments. In this case, leachate chemistry could not be explained simply by soil chemical characteristics such as ion exchange capacity or weathering potential. Searcy et al. (2003) examined the influence of parent material and aspect on soil and vegetation distribution in mountains of Massachusetts USA. They found that only $51 \%$ of the variance in soil chemistry was due to parent material differences while differences in vegetation composition were due to both parent material and aspect.

Factors of soil formation suggest that forest soils become increasingly acidic over time for a number of reasons including base cation uptake by vegetation, humus formation, soil leaching wherever precipitation exceeds mean annual evapotranspiration (Johnson, 1987), and base cation removal during forest harvesting (Federer et al., 1989; Knoepp and Swank, 1997). Cation losses have been accelerated by acidic deposition and $\mathrm{Ca}$ depletion has occurred in many forest ecosystems (Joslin et al., 1992; Knoepp and Swank, 1995; Graf Pannatier et al., 2004; Likens, 2004; McLaughlin, 2014). In high elevation red spruce, Joslin et al. (1992) showed that base cations $\mathrm{Ca}$ and $\mathrm{Mg}$ were preferentially leached out of surface soils, tree ring chemistry 
631 showed decreasing Ca:Al ratios over time, suggesting that soil acidity and Al solubility had 632 increased. In Switzerland, Graf Pannatier et al. (2004) examined ratios of base cations to 633 aluminum (BC:Al) in forest soils and soil solution to estimate acidic deposition response. Their 634 data showed that the $\mathrm{pH}-\mathrm{Al}$ relationship was curvilinear and that soils with $\% \mathrm{BS}<10$ and $635 \mathrm{BC}: \mathrm{Al}$ ratios $<0.2$ generally had soil solutions with low $\mathrm{BC}: \mathrm{Al}$ ratios and the potential for root 636 toxicity. In our study, soil \%BS was often $<10 \%$ and mineral soil exchangeable Ca:Al ratio was $637<1.0$ (mol:mol). Similar to the findings of Graf Pannatier et al. (2004), we found that \%BS in 638 deep soil was a significant covariate informing variability in stream Ca:Al molar ratio (Table 3). 639 Although decreasing atmospheric $\mathrm{SO}_{4}$ deposition has resulted in decreasing soil solution 640 and stream $\mathrm{SO}_{4}$ in some studies (Fölster et al., 2003; Pardo and Duarte, 2007), we found no 641 relationships between stream chemistry and soil total $\mathrm{S}$ or extractable $\mathrm{SO}_{4}$ in any soil layer (data 642 not shown). However, soil solution or stream $\mathrm{SO}_{4}$ may not respond immediately to changes in 643 deposition due to other sources of $\mathrm{SO}_{4}$ within the soil profile and the watershed (Bailey et al., 644 2004; Morth et al., 2005; Mitchell et al., 2008; Pannatier et al., 2011; Rice et al., 2014). These 645 sources include weathering of mineral S in bedrock, dry deposition inputs, mineralization of 646 organic $\mathrm{S}$, desorption of soil $\mathrm{SO}_{4}$, and the oxidation of recently formed $\mathrm{SO}_{2}$ in anoxic areas 647 draining to the stream. Responses to declining $\mathrm{SO}_{4}$ deposition may also vary within the soil 648 profile. For example, Fölster et al. (2003) measured declining soil solution $\mathrm{SO}_{4}$ in catchments in 649 Sweden. They found greater $\mathrm{SO}_{4}$ declines in soil $\mathrm{E}$ horizons compared to B horizons suggesting 650 that desorption of previously accumulated $\mathrm{SO}_{4}$ in $\mathrm{B}$ horizons was occurring more slowly in 651 response to decreasing acid deposition. Due to close proximity, we expected a high level of connectivity between the riparian 653 zone soil chemistry and the stream, especially during sample dates with greater baseflow (i.e., 
654 spring and early summer) (Christopher et al. 2006, Lutz et al. 2012). However, we identified 655 fewer significant covariates of stream acidity (ANC, $\mathrm{pH}$, and $\mathrm{Ca}$ :Al molar ratio) from riparian 656 zones (Table 4) compared to the catchment scale suggesting little riparian-stream connectivity

657 (Table 3). This could be due to sample collection during baseflow conditions. Other studies, for 658 example, Murdoch and Shanley $(2006 \mathrm{a}, \mathrm{b})$, have shown that sampling during baseflow or during 659 a storm event can affect stream chemistry and observed trends in declining stream acidity. We 660 collected stream samples seasonally and compared indicator sample collections at the riparian 661 and catchment scale in order to evaluate soil-stream connectivity. Interestingly, we found strong 662 relationships between stream chemistry and soil O-horizon and mineral surface and deep soils.

\subsection{Catchment liming and mitigation}

665

666 Our second objective was to make laboratory based estimates of catchment lime requirements 667 and evaluate how liming at a catchment scale may improve stream chemistry. Soils and stream 668 recovery from acidic deposition is a slow process that may be accelerated by land managers 669 through liming. The specific goals of liming streams or catchments are to increase stream ANC, $670 \mathrm{pH}$ and $\mathrm{Ca}$ while decreasing $\mathrm{SO}_{4}$ and $\mathrm{Al}$. Restoration practices include adding lime directly to

671 stream water or treating the entire catchment with reported lime additions ranging from 5 to 30

$672 \mathrm{Mg} \mathrm{ha}^{-1}$ (Clair and Hindar, 2005). Our estimated lime additions fall within this broad range, with 67311.6 to $21.1 \mathrm{Mg} \mathrm{ha}^{-1} \mathrm{CaCO}_{3}$ required to increase the top $30 \mathrm{~cm}$ of soil to $\mathrm{pH} 5.5$. Our estimated 674 lime requirement did not differ among the three watersheds we studied. However, as reported in 675 the literature (Reid and Watmough, 2014), riparian zone soils which have greater organic C 676 content, required less lime to increase soil $\mathrm{pH}$ to 5.5. Understanding stream acidity responses to 
677 riparian zone or catchment level liming would require experimental lime addition, ideally in

678 catchments with the low extractable Ca and high stream acidity such as, those in the Santeetlah

679 Creek watershed.

680 In an extensive literature review, Clair and Hindar (2005) examined liming experiments 681 conducted from the 1980 s to 2000 , including various chemical compounds and methods of 682 application. Overall, their review found that directly adding lime to the stream channel 683 significantly improved the stream $\mathrm{pH}$, chemistry, and suitability for fish populations. Their 684 review also presents research suggesting that while catchment level liming was effective at 685 increasing stream $\mathrm{pH}$ and $\mathrm{Ca}$ concentrations the effects on inorganic $\mathrm{Al}$ concentrations were 686 variable. Johnson et al. (1995) presented long term soil and stream chemistry results of a 687 catchment level liming experiment in the southern Appalachians; $6.7 \mathrm{Mg} \mathrm{ha}^{-1}$ dolomitic 688 limestone was added in a single application. They found liming increased $\mathrm{Ca}, \mathrm{Mg}$ and percent 689 base saturation in surface $(0-15 \mathrm{~cm})$ and subsurface $(15-30 \mathrm{~cm})$ mineral soils but there was little 690 movement of the added lime to deep soils $(30+\mathrm{cm})$; stream Ca was increased for almost 20 691 years. A study by Long et al. (2015) examined soil responses to a liming treatment on sugar 692 maple stands in northern Pennsylvania; 22.4 $\mathrm{Mg} \mathrm{ha}^{-1}$ dolomitic lime was added in a single 693 application. They found increases in exchangeable $\mathrm{Ca}$ and $\mathrm{Mg}$ to soil depths of $45 \mathrm{~cm}$ along 694 with increased foliar Ca, 21 years after treatment. Ormerod and Durrance (2009) examined 25 695 year stream chemistry responses to reductions in acidic deposition and liming in moorland and 696 forest catchments; 9 to $25 \mathrm{Mg} \mathrm{ha}^{-1}$ calcium carbonate added in a single application. Declining 697 acidic deposition, without lime treatment, resulted in increased stream water $\mathrm{pH}$ with values 698 increasing from 4.8-5.2 while liming increased stream $\mathrm{pH}$ to 5.9. Our estimated lime 699 requirements for high elevation, mixed deciduous forests were greater than that applied by 
700

701

702

703

704

705

706

707

708

709

710

711

712

713

714

715

716

717

718

719

720

721

722

Johnson et al. (1995), but are within the range applied by others in the northeastern USA (Clair and Hindar, 2005; Long et al., 2015), suggesting that lime applications in these forests would result in long-term soil and stream responses.

Research studies have also examined base cation additions, specifically $\mathrm{Ca}$, without $\mathrm{pH}$ adjustment, on soil chemistry, vegetation $\mathrm{Ca}$, and stream chemistry. In the Hubbard Brook Experimental Forest, wollastonite $\left(\mathrm{CaSiO}_{3}\right)\left(0.85 \mathrm{Mg} \mathrm{Ca} \mathrm{ha}^{-1}\right)$ was applied to a forested catchment with $\mathrm{Ca}$ depleted soils and the responses have been extensively studied (Juice et al., 2006; Nezat et al., 2010; Green et al., 2013). Juice et al. (2006) found that Ca addition increased the $\mathrm{pH}$ of the $\mathrm{Oi}+\mathrm{Oe}$ horizons from 3.8 to 5.0 and the Oa horizon from 3.9 to 4.2 within 3 years of treatment; foliar and fine root Ca concentrations also increased. Nezat et al. (2010) found that it took 3-9 years for the applied Ca to infiltrate the deeper flow paths in the soil profile before it was exported to the stream. Within this same watershed, Green et al. (2013) found that stream flow was increased due to reduced rates of evapotranspiration for three years, before returning to pre-treatment levels. They attributed this to increased aboveground productivity due to the short term correction of a nutrient imbalance, as found in other studies (e.g., (Kulmatiski et al., 2007).

\section{Conclusions}

We studied three watersheds in the southern Appalachian mountains, North River (NR), Santeetlah Creek (SC) and the North Fork of the French Broad (FB), in an effort to identify catchment (i.e., smaller $1^{\text {st }}$ order catchments within the $3^{\text {rd }}$ order watersheds) indicators of stream acidity (ANC, $\mathrm{pH}$, and $\mathrm{Ca}: \mathrm{Al}$ molar ratio) that would aid land managers in selecting catchments to focus restoration efforts. Catchments represented a broad range of stream acidity and 
723 indicators of sensitivity to acidic deposition. We found that vegetation (stand basal area,

724 dominant tree height and tree diameter), soil A-horizon depth, deep soil C concentrations and

725 indicators of soil parent material (total elemental $\mathrm{Ca}$ and extractable Ca:total Ca ratio) were

726 significant covariates for stream $\mathrm{ANC}, \mathrm{pH}$, and $\mathrm{Ca}: \mathrm{Al}$ ratio. O-horizon total $\mathrm{N}$ and $\mathrm{Al}$

727 concentrations were also strongly related to stream acidity.

728 Laboratory estimated lime requirements, which were within the broad range found in

729 other studies, varied by as much as $8 \mathrm{Mg} \mathrm{ha}^{-1}$ among catchments due to differences in soil

730 chemistry. Expected stream responses to lime application may also differ, depending on

731 overstory species, soil-stream connectivity and other soil processes. Long-term lime application

732 studies are recommended for these high elevation, mixed deciduous forests to evaluate how they

733 will respond to lime application. Nonetheless, our initial estimates of lime requirement will help

734 land managers target the catchments and streams where lime application would have the greatest

735 probability of reducing stream acidity.

736 Our measures of how catchment biotic, physical and chemical indicators related to stream

737 acidity could provide insight to selecting forested catchments for restoration treatments.

738 However, full understanding of the applicability of these indicators in targeting restoration

739 efforts will require an effort that includes widespread regional sampling to capture a greater

740 range of watershed conditions and recovery patterns.

741

742 Acknowledgements

743

744 This study was supported by the USDA Forest Service, Region 8, TVA Settlement Funds, 745 USDA Forest Service, Southern Research Station, Coweeta Hydrologic Laboratory project 
746 funds, and by NSF grants DEB0218001 and DEB0823293 to the Coweeta LTER program at the

747 University of Georgia. Any opinions, findings, conclusions, or recommendations expressed in

748 the material are those of the authors and do not necessarily reflect the views of the USDA Forest

749 Service. The authors declare that experiments complied with the current laws of the United

750 States of America and there are no conflicts of interest. We thank Bob McCollum, Patsy

751 Clinton, Chris Worley, and Cindi Brown for their assistance with this research. We are grateful

752 to Dr. Carl Trettin and anonymous reviewers for their constructive comments on the manuscript. 


\section{$754 \quad$ Figure Headings}

755 Figure 1. Location of three watersheds sampled in this study.

756 Figure 2. Plot characterization variables were measured at each riparian and hillslope plots. A-

757 horizon and total soil profile depth, basal area, diameter at breast height (DBH) and mean height

758 of the 6 dominant overstory trees, and basal area of Quercus spp. and Acer spp. Plot values for

759 each variable are shown with North River $(\bullet)$, Santeetlah Creek $(\boldsymbol{\Delta})$, and North Fork of the

760 French Broad ( $\bullet$ ). Box plots show watershed median value, along with the $10^{\text {th }}, 25^{\text {th }}, 75^{\text {th }}$ and

$76190^{\text {th }}$ percentiles.

762 Figure 3. Catchment stream chemistry including all sample dates (early summer, mid-summer,

763 fall and spring) for acid neutralizing capacity (ANC), $\mathrm{pH}$, and $\log _{10}$ molar Ca:Al ratio. Shown

764 are catchment values for each watershed, North River $(\bullet)$, Santeetlah Creek ( $\boldsymbol{\Delta})$, and North Fork

765 of the French Broad ( $\mathbf{\square})$. Box plots show watershed median value, along with the $10^{\text {th }}, 25^{\text {th }}, 75^{\text {th }}$

766 and $90^{\text {th }}$ percentiles.

767 Figure 4. Relationship between catchment non-chemical characteristics that significantly inform

768 stream chemistry variability and stream chemistry: elevation versus ANC, $\log _{10}$ mineral soil A-

769 horizon depth and catchment basal area versus $\mathrm{pH}$, and mean dominant tree height versus $\log _{10}$

770 molar Ca:Al. Data shown are mean catchment values for each watershed, North River $(\bullet)$,

771 Santeetlah Creek ( $\boldsymbol{\Delta})$, and North Fork of the French Broad ( $\boldsymbol{\square})$.

772 Figure 5. Relationship between catchment geochemical characteristics that significantly inform

773 stream chemistry variability and stream chemistry: soil profile total Ca content versus ANC,

$774 \log _{10}$ ratio of extractable to total $\mathrm{Ca}$ in surface mineral soil versus $\mathrm{pH}$, and surface mineral soil

775 Fe:Al ratio and litterfall Ca:Al versus $\log _{10}$ molar Ca:Al. Data shown are mean catchment values 
776 for each watershed, North River $(\bullet)$, Santeetlah Creek ( $\Delta)$, and North Fork of the French Broad $777(\mathbf{\square})$.

778 Figure 6. Relationship between catchment O-horizon physical and chemical characteristics that 779 significantly inform stream chemistry variability and stream chemistry: total $\mathrm{N}$ concentration in 780 the $\mathrm{Oe}+\mathrm{Oa}$ horizon versus $\mathrm{ANC}, \log _{10}$ Oi horizon mass versus $\mathrm{pH}$, and $\log _{10}$ total $\mathrm{Al}$

781 concentration in the Oi horizon versus $\log _{10}$ molar Ca:Al. Data shown are mean catchment 782 values for each watershed, North River $(\bullet)$, Santeetlah Creek $(\boldsymbol{\Delta})$, and North Fork of the French 783 Broad ( $\mathbf{a})$ for all sample dates (early summer, mid-summer, fall and spring).

784 Figure 7. Relationship between catchment mineral soil chemical characteristics that significantly 785 inform stream chemistry variability and stream chemistry: total C concentration in the deep 786 mineral soil and $\log _{10}$ extractable $\mathrm{Al}$ in the surface mineral soil versus $\mathrm{ANC}$, total C 787 concentration in the deep mineral soil versus $\mathrm{pH}$, and $\log _{10} \%$ base saturation in deep mineral soil 788 versus $\log _{10}$ molar Ca:Al. Data shown are mean catchment values for each watershed, North 789 River $(\bullet)$, Santeetlah Creek ( $\boldsymbol{\Delta})$, and North Fork of the French Broad ( $\boldsymbol{\bullet}$ ) for all sample dates 790 (early summer, mid-summer, fall and spring).

791 Figure 8. Estimated lime required to increase mineral soil to $\mathrm{pH} 5.5$ for the surface soil (0-10 $792 \mathrm{~cm})$ and surface plus subsurface soil $(0-30 \mathrm{~cm})$. Shown are plot values for each watershed, 793 North River $(\bullet)$, Santeetlah Creek ( $\boldsymbol{\Delta})$, and North Fork of the French Broad ( $\boldsymbol{\bullet})$. Box plots show 794 watershed median value, along with the $10^{\text {th }}, 25^{\text {th }}, 75^{\text {th }}$ and $90^{\text {th }}$ percentiles.

795 Figure 9. Relationship between catchment stream elevation and stream chemistry: ANC, $\mathrm{pH}$, 796 and $\log _{10}$ molar Ca:Al. Data shown are mean catchment values for each watershed, North River 797 (•), Santeetlah Creek ( $\boldsymbol{\Delta})$, and North Fork of the French Broad ( $\boldsymbol{\bullet})$. 


\section{References}

Alban, D.H., 1982. Effects of nutrient accumulation by aspen, spruce, and pine on soil properties. Soil Science Sociey of America Journal 46, 853-861.

Bailey, S., Mayer, B., Mitchell, M., 2004. Evidence for influence of mineral weathering on stream water sulphate in Vermont and New Hampshire (USA). Hydrological Processes $18,1639-1653$.

Bulger, A.J., Cosby, B.J., Webb, J.R., 2000. Current, reconstructed past, and projected future status of brook trout (Salvelinus fontinalis) streams in Virginia. Canadian Journal of Fisheries and Aquatic Sciences 57, 1515-1523.

Buol, S.W., Southard, F.J., Graham, R.C., McDaniel, P.A., 2011. Soil Genesis and Classification. John Wiley \& Sons, Inc., Iowa State University Press.

Burns, D.A., Lynch, J.A., Cosby, B.J., Fenn, M.E., Baron, J.S., U.S. E.P.A., C.A.M.D., 2011. National Acid Precipitation Assessment Program Report to congress 2011: An Integrated Assessment. In. National Science and Technology Council, Washington, DC, p. 114.

Christopher, S.F., Page, B.D., Campbell, J.L., Mitchell, M.J., 2006. Contrasting stream water $\mathrm{NO}_{3}$ - and $\mathrm{Ca}^{2+}$ in two nearly adjacent catchments: the role of soil $\mathrm{Ca}$ and forest vegetation. Global Change Biology 12, 364-381.

Clair, T.A., Hindar, A., 2005. Liming for the mitigation of acid rain effects in freshwaters: a review of recent results. Environmental Reviews 13, 91-128.

Driscoll, C.T., Driscoll, K.M., Roy, K.M., Mitchell, M.J., 2003. Chemical response of lakes in the Adirondack Region of New York to declines in acidic deposition. Environmental Science \& Technology 37, 2036-2042. 
821 Elliott, K.J., Knoepp, J.D., Vose, J.M., Jackson, W.A., 2013. Interacting effects of wildfire

822

823

824

825

826

827

828

829

830

831

832

833

834

835

836

837

838

839

840

841

842 severity and liming on nutrient cycling in a southern Appalachian wilderness area. Plant and Soil 366, 165-183.

Elliott, K.J., Swank, W.T., 2008. Long-term changes in forest composition and diversity following early logging (1919-1923) and the decline of American chestnut (Castanea dentata). Plant Ecology 197, 155-172.

Elliott, K.J., Vose, J.M., Knoepp, J.D., Clinton, B.D., Kloeppel, B.D., 2015. Functional Role of the Herbaceous Layer in Eastern Deciduous Forest Ecosystems. Ecosystems 18, 221-236.

Elliott, K.J., Vose, J.M., Knoepp, J.D., Johnson, D.W., Swank, W.T., Jackson, W.A., 2008. Simulated effects of sulfur deposition on nutrient cycling in Class I Wilderness Areas. Journal of Environmental Quality 37, 1419-1431.

Elliott, K.J., Vose, J.M., Swank, W.T., Bolstad, P.V., 1999. Long-term patterns in vegetation-site relationships in a southern Appalachian Forest. Journal of the Torrey Botanical Society $126,320-334$.

Federer, C.A., Hornbeck, J.W., Tritton, L.M., Martin, C.W., Pierce, R.S., Smith, C.T., 1989. Long-term depletion of calcium and other nutrients in eastern US forests. Environmental Management 13, 593-601.

Fölster, J., Bringmark, L., Lundin, L., 2003. Temporal and spatial variations in soil water chemistry at three acid forest sites. Water, Air, and Soil Pollution 146, 171-195.

Graf Pannatier, E., Walthert, L., Blaser, P., 2004. Solution chemistry in acid forest soils: Are the BC: Al ratios as critical as expected in Switzerland? Journal of Plant Nutrition and Soil Science 167, 160-168. 
843 Greaver, T.L., Sullivan, T.J., Herrick, J.D., Barber, M.C., Baron, J.S., Cosby, B.J., Deerhake,

844

845

846

847

848

849

850

851

852

853

854

855

856

857

858

859

860

861

862

863

864
M.E., Dennis, R.L., Dubois, J.J.B., Goodale, C.L., Herlihy, A.T., Lawrence, G.B., Liu, L.L., Lynch, J.A., Novak, K.J., 2012. Ecological effects of nitrogen and sulfur air pollution in the US: what do we know? Frontiers in Ecology and the Environment 10, 365-372.

Green, M.B., Bailey, A.S., Bailey, S.W., Battles, J.J., Campbell, J.L., Driscoll, C.T., Fahey, T.J., Lepine, L.C., Likens, G.E., Ollinger, S.V., 2013. Decreased water flowing from a forest amended with calcium silicate. Proceedings of the National Academy of Sciences 110, 5999-6003.

Grieve, I.C., 1999. Effects of parent material on the chemical composition of soil drainage waters. Geoderma 90, 49-64.

Hahm, W.J., Riebe, C.S., Lukens, C.E., Araki, S., 2014. Bedrock composition regulates mountain ecosystems and landscape evolution. Proceedings of the National Academy of Sciences 111, 3338-3343.

Hallet, R.A., Hornbeck, J.W., 1997. Foliar and soil nutrient relationships in red oak and white pine forests. Canadian Journal of Forest Research 27, 1233-1244.

Hossner, L.R., 1996. Dissolution for total elemental analysis. In: Sparks, D.L. (Ed.), Methods of Soil Analysis: Chemical Methods. Soil Science Society of America, Inc., Madison, Wisconsin, pp. 49-64.

Huettl, R.a.H.Z., 1993. Liming as a mitigation tool in Germany's declining forests-reviewing results from former and recent trials. Forest Ecology and Management 61, 325-338.

Hursh, C.R., 1928. Litter keeps forest soil productive. Southern Lumberman 133, 219-221. 
Hurvich, C.M., Tsai, C.-L., 1991. Bias of the corrected AIC criterion for underfitted regression and time series models. Biometrika 78, 499-509.

Jenny, H., 1941. Factors of soil formation: A system of quantitative pedology. McGraw-Hill Book Company, Inc., New York, NY.

Joergensen, R.G., Scholle, G.A., Wolters, V., 2009. Dynamics of mineral components in the forest floor of an acidic beech (Fagus sylvatica L.) forest. European Journal of Soil Biology 45, 285-289.

Johnson, D.W., 1987. A discussion of the changes in soil acidity due to natural processes and acid deposition. In: Hutchinson, T.C., Meema, K.M. (Eds.), Effects of Atmospheric Pollutants on Forests, Wetland, and Agicultural Ecosystems. Springer-Verlag, Berlin.

Johnson, D.W., Cresser, M.S., Nilsson, S.I., Turner, J., Ulrich, B., Binkley, D., Cole, D.W., 1991. Soil changes in forest ecosystems: evidence for and probable causes. Proc. Royal Soc. Edinburgh 97B, 81-116.

Johnson, D.W., Lindberg, S.E., Pitelka, L.F. (Eds.), 1992. Atmospheric deposition and forest nutrient cycling: a synthesis of the integrated forest study. Springer-Verlag, New York.

Johnson, D.W., Swank, W.T., Vose, J.M., 1995. Effects of liming on soils and streamwaters in a deciduous forest: Comparison of field results and simulations. Journal of Environmental Quality 24, 1104-1117.

Johnson, D.W., Turner, J., Kelly, J.M., 1982. The effects of acid rain on forest nutrient status. Water Res. Res. 18, 449-461.

Joslin, J.D., Kelly, J.M., Van Miegroet, H., 1992. Soil chemistry and nutrition of North American spruce-fir stands: evidence of recent change. Journal of Environmental Quality $21,12-30$. 
Juice, S.M., Fahey, T.J., Siccama, T.G., Driscoll, C.T., Denny, E.G., Eagar, C., Cleavitt, N.L., Minocha, R., Richardson, A.D., 2006. Response of sugar maple to calcium addition to northern hardwood forest. Ecology 87, 1267-1280.

Knoepp, J.D., Coleman, D.C., Crossley, D.A., Jr., Clark, J.S., 2000. Biological indices of soil quality: an ecosystem case study of their use. Forest Ecology and Management 138, 357368.

Knoepp, J.D., Swank, W.T., 1995. Long-Term Soil Chemistry Changes in Aggrading Forest Ecosystems - Reply. Soil Science Society of America Journal 59, 569-569.

Knoepp, J.D., Swank, W.T., 1997. Forest management effects on surface soil carbon and nitrogen. Soil Science Society of America Journal 61, 928-935.

Knoepp, J.D., Swank, W.T., 1998. Rates of nitrogen mineralization across an elevation and vegetation gradient in the southern Appalachians. Plant and Soil 204, 235-241.

Knoepp, J.D., Vose, J.M., Clinton, B.D., Hunter, M.D., 2011. Hemlock infestation and mortality: impacts on nutrient pools and cycling in Appalachian forests. Soil Science Society of America Journal 75, 1935-1945.

Knoepp, J.D., Vose, J.M., Swank, W.T., 2008. Nitrogen deposition and cycling across an elevation and vegetation gradient in southern Appalachian forests. International Journal of Environmental Studies 65, 389-408.

Kulmatiski, A., Vogt, K.A., Vogt, D.J., Wargo, P.M., Tilley, J.P., Siccama, T.G., Sigurdardottir, R., Ludwig, D., 2007. Nitrogen and calcium additions increase forest growth in northeastern USA spruce-fir forests. Canadian Journal of Forest Research-Revue Canadienne De Recherche Forestiere 37, 1574-1585. 
910 911

Kuo, S., 1996. Phosphorus. In: Sparks, D.L. (Ed.), Methods of Soil Analysis: Chemical Methods. Soil Science Society of America, Inc., Madison, Wisconsin, pp. 869-919.

Lawrence, G.B., David, M.B., Shortle, W.C., 1995. A new mechanism for calcium loss in forestfloor soils. Nature 378, 162-165.

Lawrence, G.B., Hazlett, P.W., Fernandez, I.J., Ouimet, R., Bailey, S.W., Shortle, W.C., Smith, K.T., Antidormi, M.R., 2015. Declining acidic deposition begins reversal of forest-soil acidification in the northeastern US and eastern Canada. Environmental Science \& Technology 49, 13103-13111.

Lawrence, G.B., Shortle, W.C., David, M.B., Smith, K.T., Warby, R.A., Lapenis, A.G., 2012. Early indications of soil recovery from acidic deposition in US red spruce forests. Soil Science Society of America Journal 76, 1407-1417.

Likens, G., Driscoll, C., Buso, D., Siccama, T., Johnson, C., Lovett, G., Fahey, T., Reiners, W., Ryan, D., Martin, C., 1998. The biogeochemistry of calcium at Hubbard Brook. Biogeochemistry 41, 89-173.

Likens, G.E., 2004. Some perspectives on long-term biogeochemical research from the Hubbard Brook Ecosystem Study. Ecology 85, 2355-2362.

Likens, G.E., Buso, D.C., 2012. Dilution and the Elusive Baseline. Environmental Science \& Technology 46, 4382-4387.

Likens, G.E., Driscoll, C.T., Buso, D.C., 1996. Long-term effects of acid rain: Response and recovery of a forest ecosystem. Science 272, 244-246.

Littell, R.C., 2007. Repeated measures analysis with clustered subjects. In, SAS Global Forum 2007: Statistics and Data Analysis. SAS, Institute Inc., p. 11. 
Littell, R.C., Henry, P.R., Ammerman, C.B., 1998. Statistical analysis of repeated measures data using SAS procedures. journal of Animal Science 76, 1216-1231.

Long, R.P., Bailey, S.W., Horsley, S.B., Hall, T.J., Swistock, B.R., DeWalle, D.R., 2015. LongTerm Effects of Forest Liming on Soil, Soil Leachate, and Foliage Chemistry in Northern Pennsylvania. Soil Science Society of America Journal 79, 1223-1236.

Lovett, G.M., Mitchell, M.J., 2004. Sugar maple and nitrogen cycling in the forests of eastern North America. Frontiers in Ecology and the Environment 2, 81-88.

Lutz, B.D., Mulholland, P.J., Bernhardt, E.S., 2012. Long-term data reveal patterns and controls on stream water chemistry in a forested stream: Walker Branch, Tennessee. Ecological Monographs 82, 367-387.

McDonnell, T.C., Sullivan, T.J., Hessburg, P.F., Reynolds, K.M., Povak, N.A., Cosby, B.J., Jackson, W., Salter, R.B., 2014. Steady-state sulfur critical loads and exceedances for protection of aquatic ecosystems in the US southern Appalachian Mountains. Journal of Environmental Management 146, 407-419.

McHale, M.R., McDonnell, J.J., Mitchell, M.J., Cirmo, C.P., 2002. A field-based study of soil water and groundwater nitrate release in an Adirondack forested watershed. Water Resources Research 38, 1031-1031.

McLaughlin, J.W., 2014. Forest Soil Calcium Dynamics and Water Quality: Implications for Forest Management Planning. Soil Science Society of America Journal 78, 1003-1020.

McNulty, S.G., Cohen, E.C., Moore Myers, J.A., Sullivan, T.J., Harbin, L., 2007. Estimates of critical acid loads and exceedances for forest soils across the conterminous United States. Environmental Pollution 149, 281-292. 
Miniat, C.F., Brown, C.L., Harper, C., Gregory, S., Welch, B., 2014. Procedures for chemical analysis at the Coweeta Hydrologic Laboratory. In, Coweeta Files. Coweeta Hydrologic Laboratory, Otto, NC, p. 206.

Mitchell, M.J., Bailey, S.W., Shanley, J.B., Mayer, B., 2008. Evaluating sulfur dynamics during storm events for three watersheds in the northeastern USA: a combined hydrological, chemical and isotopic approach. Hydrological Processes 22, 4023-4034.

Morth, C.M., Torssander, P., Kjonaas, O.J., Stuanes, A.O., Moldan, F., Giesler, R., 2005. Mineralization of organic sulfur delays recovery from anthropogenic acidification. Environmental Science \& Technology 39, 5234-5240.

Murdoch, P.S., Shanley, J.B., 2006a. Detection of water quality trends at high, median, and low flow in a Catskill Mountain stream, New York, through a new statistical method. Water Resources Research 42.

Murdoch, P.S., Shanley, J.B., 2006b. Flow-specific trends in river-water quality resulting from the effects of the clean air act in three mesoscale, forested river basins in the northeastern United States through 2002. Environmental Monitoring and Assessment 120, 1-25.

NADP, 2007. (NRSP-3). In. National Atmospheric Deposition Program Office, Illinois State Water Survey, 2204 Griffith Dr., Champaign, IL 61820.

Nezat, C.A., Blum, J.D., Driscoll, C.T., 2010. Patterns of Ca/Sr and $87 \mathrm{Sr} / 86 \mathrm{Sr}$ variation before and after a whole watershed $\mathrm{CaSiO} 3$ addition at the Hubbard Brook Experimental Forest, USA. Geochimica et Cosmochimica Acta 74, 3129-3142.

Ordoñez, J.C., Van Bodegom, P.M., Witte, J.P.M., Wright, I.J., Reich, P.B., Aerts, R., 2009. A global study of relationships between leaf traits, climate and soil measures of nutrient fertility. Global Ecology and Biogeography 18, 137-149. 
977 Ormerod, S.J., Durance, I., 2009. Restoration and recovery from acidification in upland Welsh

978

979

980

981

982

983

984

985

986

987

988

989

990

991

992

993

994

995

996

997

998

streams over 25 years. Journal of Applied Ecology 46, 164-174.

Pannatier, E.G., Thimonier, A., Schmitt, M., Walthert, L., Waldner, P., 2011. A decade of monitoring at Swiss Long-Term Forest Ecosystem Research (LWF) sites: can we observe trends in atmospheric acid deposition and in soil solution acidity? Environmental Monitoring and Assessment 174, 3-30.

Pardo, L.H., Duarte, N., 2007. Assessment of effects of acidic deposition on forested ecosystems in Great Smoky Mountains National Park using critical loads for sulfur and nitrogen. USDA Forest Service, Burlington, VT.

Perala, D.A., Alban, D.H., 1982. Rates of forest floor decomposition and nutrient turnover in aspen, pine, and spruce stands on two soils. In. North Central Forest Experiment Station; Forest Service-U.S. Department of Agriculture, St. Paul, Minnesota, p. 5.

Priha, O., Smolander, A., 1995. Nitrification, denitrification and microbial biomass $\mathrm{N}$ in soil from two N-fertilized and limed Norway Spruce forests. Soil Biology and Biochemistry $27,305-310$.

Qiao, Y., Miao, S., Silva, L.C.R., Horwath, W.R., 2014. Understory species regulate litter decomposition and accumulation of $\mathrm{C}$ and $\mathrm{N}$ in forest soils: a long-term dual-isotope experiment. Forest Ecology and Management 329, 318-327.

Ramann, E., 1928. The evolution and classifications of soils. W. Heffer \& Sons, Ltd., Cambridge.

Rauland-Rasmussen, K., Vejre, H., 1995. Effect of tree species and soil properties on nutrient immobilization in the forest floor. Plant and Soil 168-169, 345-352. 
Reid, C., Watmough, S.A., 2014. Evaluating the effects of liming and wood-ash treatment on forest ecosystems through systematic meta-analysis. Canadian Journal of Forest Research 44, 867-885.

Rice, K.C., Deviney, F.A., Hornberger, G.M., Webb, J.R., 2006. Predicting the vulnerability of streams to episodic acidification and potential effects on aquatic biotia in Shenandoah National Park, Virginia. In, Scientific Investigations Report. U.S. Department of the Interior, U.S. Geological Survey, p. 51.

Rice, K.C., Scanlon, T.M., Lynch, J.A., Cosby, B.J., 2014. Decreased atmospheric sulfur deposition across the southeastern US: when will watersheds release stored sulfate? Environmental Science \& Technology 48, 10071-10078.

SAS, 2013. SAS/STAT 9.3 User's Guide. SAS Institute Inc., Cary, NC USA.

Searcy, K.B., Wilson, B.F., Fownes, J.H., 2003. Influence of bedrock and aspect on soils and plant distribution in the Holyoke Range, Massachusetts. Journal of the Torrey Botanical Society $130,158-169$.

Sims, J.T., 1996. Lime Requirement. In: Sparks, D.L. (Ed.), Methods of Soil Analysis: Chemical Methods. Soil Science Society of America, Inc., Madison, Wisconsin, pp. 491-515.

Soil_Survey_Staff, 2014. Official Soil Series Descriptions. In: Natural Resource Conservation Service, U.S.D.o.A. (Ed.).

Sullivan, T.J., Cosby, B.J., Jackson, W.A., Snyder, K.U., Herlihy, A.T., 2011. Acidification and prognosis for future recovery of acid-sensitive streams in the Southern Blue Ridge Province. Water, Air, \& Soil Pollution 219, 11-26.

Sullivan, T.J., Crosby, B.J., Webb, J.R., Dennis, R.L., Bulger, A.J., Deviney, F.A., 2008. Streamwater acid-base chemistry and critical loads of atmospheric sulfur deposition in 
Shenandoah National Park, Virginia. Environmental Monitoring and Assessment 137, 85-99.

Sullivan, T.J., Webb, J.R., Snyder, K.U., Herlihy, A.T., Cosby, B.J., 2007. Spatial distribution of acid-sensitive and acid-impacted streams in relation to watershed features in the Southern Appalachian Mountains. Water Air and Soil Pollution 182, 57-71.

Swank, W.T., 1988. Characterization of baseline precipitation and stream chemistry and nutrient budgets for control watersheds. In: Swank, W.T., Crossley, D.A., Jr. (Eds.), Forest Hydrology and Ecology at Coweeta. Springer-Verlag, New York, p. 469.

Swank, W.T., Vose, J.M., 1997. Long-term nitrogen dynamics of Coweeta forested watersheds in the southeastern United States of America. Global Biogeochemical Cycles 11, 657671.

Swift Jr., L.W., Cunningham, G.B., Douglass, J.E., 1988. Climatology and hydrology. In: Swank, W.T., Crossley, D.A., Jr. (Eds.), Forest Hydrology and Ecology at Coweeta. Springer-Verlag, New York, pp. 35-56.

Talhelm, A.F., Pregitzer, K.S., Burton, A.J., Zak, D.R., 2012. Air pollution and the changing biogeochemistry of northern forests. Frontiers in Ecology and the Environment 10, 181185.

U.S. E.P.A., C.A.A.O., 2015. Progress cleaning the air and improving people's health. In. U.S. E.P.A., https://www.epa.gov/clean-air-act-overview/progress-cleaning-air-andimproving-peoples-health\#emissions.

USEPA, 1983. Methods for chemical analysis of water and waste. Determination of nitrogen as ammonia. Method 350.1. Environmental Monitoring and Support Lab., Office of Research and Development, USEPA, Cincinnati, OH. 
1045 Velbel, M.A., 1985. Geochemical mass balances and weathering rates in forested watersheds of 1046 the southern Blue Ridge. American Journal of Science 285, 904-930.

1047 Velbel, M.A., 1988. Weathering and soil-forming processes. In: Swank, W.T., Crossley, D.A., 1048 Jr. (Eds.), Forest Hydrology and Ecology at Coweeta. Springer-Verlag, New York, p. 1049469.

1050 Velbel, M.A., Price, J.R., 2007. Solute geochemical mass-balances and mineral weathering rates 1051 in small watersheds: Methodology, recent advances, and future directions. Applied 1052 Geochemistry 22, 1682-1700.

1053 Weathers, K.C., Lovett, G.M., Likens, G.E., Lathrop, R., 2000. The effect of landscape features 1054 on deposition to Hunter Mountain, Catskill Mountains, New York. Ecological $1055 \quad$ Applications 10, 528-540.

1056 Weathers, K.C., Simkin, S.M., Lovett, G.M., Lindberg, S.E., 2006. Empirical modeling of 1057 atmosphere deposition in mountainous landscapes. Ecological Applications 16, 1590$1058 \quad 1607$.

1059 Wurzburger, N., Hendrick, R.L., 2007. Rhododendron thickets alter N cycling and soil 1060 extracellular enzyme activities in southern Appalachian hardwood forests. Pedobiologia $1061 \quad 50,563-576$. 
Table 1. Variables measured for catchment characterization, catchment geochemical characterization, soil O-horizon, mineral soil, and stream chemistry. Variables marked with '*' were identified as significant covariates in stream chemistry statistical models (Tables 3 and 4).

\begin{tabular}{|c|c|}
\hline Dataset & Variables measured \\
\hline \multirow[t]{8}{*}{ Catchment characteristics } & Elevation $(\mathrm{m})^{*}$ \\
\hline & Slope and aspect (degrees) \\
\hline & Soil morphology (A horizon, profile depth; $\mathrm{cm}$ )* \\
\hline & O-horizon morphology (cm depth) \\
\hline & Overstory basal area $\left(\mathrm{m}^{2} \mathrm{ha}^{-1}\right)^{*}$ \\
\hline & Overstory species composition \\
\hline & Height of 6 dominant trees $(\mathrm{m})^{*}$ \\
\hline & DBH of all trees $(\mathrm{cm})^{*}$ \\
\hline \multirow{4}{*}{$\begin{array}{l}\text { Catchment geochemical } \\
\text { characteristics }\end{array}$} & Nutrient Uptake index; litterfall represented by November Oi-horizon collection* \\
\hline & Soil total elemental analysis $\left(\mathrm{g} \mathrm{kg}^{-1}\right)(\mathrm{Ca}, \mathrm{Mg}, K, \mathrm{Na}, \mathrm{Al}, \mathrm{P}, \text { calculated Felsic:Mafic, } \mathrm{Fe}: \mathrm{Al})^{*}$ \\
\hline & Total mineral soil elemental nutrient content $\left(\mathrm{kg} \mathrm{ha}^{-1}\right)^{*}$ \\
\hline & Total mineral soil extractable nutrient content $\left(\mathrm{kg} \mathrm{ha}^{-1}\right)$ \\
\hline \multirow{4}{*}{$\begin{array}{l}\text { Soil O-horizon; sampled by date and } \\
\text { horizon }\end{array}$} & Mass per unit area $\left(\mathrm{g} \mathrm{m}^{-2}\right)^{*}$ \\
\hline & Total base cations $\left(\mathrm{g} \mathrm{kg}^{-1}\right)(C a, M g, K, N a)$ \\
\hline & Total $\mathrm{Al}\left(\mathrm{g} \mathrm{kg}^{-1}\right)^{*}$ \\
\hline & Total $\mathrm{C}$ and $\mathrm{N}\left(\mathrm{g} \mathrm{kg}^{-1}\right)^{*}$ \\
\hline \multirow{8}{*}{$\begin{array}{l}\text { Mineral soil; sampled by date and } \\
\text { soil depth }\end{array}$} & $\mathrm{pH}$ \\
\hline & Extractable base cations $\left(\mathrm{g} \mathrm{kg}^{-1}\right)(\mathrm{Ca}, \mathrm{Mg}, \mathrm{K}, \mathrm{Na})$ \\
\hline & Base saturation $(\%) *$ \\
\hline & $\operatorname{ECEC~}\left(\mathrm{cmol}_{\mathrm{c}} \mathrm{kg}^{-1}\right)$ \\
\hline & Extractable $\mathrm{Al}\left(\mathrm{g} \mathrm{kg}^{-1}\right)^{*}$ \\
\hline & Lime Requirement (to $\mathrm{pH}$ 5.5) \\
\hline & Total $\mathrm{C}$ and $\mathrm{N}\left(\mathrm{g} \mathrm{kg}^{-1}\right)^{*}$ \\
\hline & Extractable $\mathrm{SO}_{4}-\mathrm{S}\left(\mathrm{g} \mathrm{kg}^{-1}\right)$ \\
\hline \multirow[t]{4}{*}{ Stream chemistry; sampled by date } & Calculated ANC \\
\hline & $\mathrm{pH}$ \\
\hline & molar Ca:Al \\
\hline & Other: $\mathrm{DOC}$ and $\mathrm{TN}, \mathrm{NO}_{3}-\mathrm{N}, \mathrm{SO}_{4}-\mathrm{S}, \mathrm{Cl}, \mathrm{NH}_{4}-\mathrm{N}$, Base cations, and $\mathrm{Al}$ \\
\hline
\end{tabular}


Table 2. Stream chemistry statistical analyses of acid neutralizing capacity $\left(\mathrm{ANC}\left(\mu \mathrm{eq} \mathrm{L}^{-1}\right)=\sum\right.$ base cations $(\mathrm{Ca}+\mathrm{Mg}+\mathrm{Na}+\mathrm{K})-\sum$ acid anions $\left.\left(\mathrm{SO}_{4}+\mathrm{NO}_{3}+\mathrm{Cl}\right)\right), \mathrm{pH}$, and the molar ratio of calcium to aluminum (mmol Ca:mmol Al). A) Repeated measures analysis including effects of watershed (fixed), date (fixed), watershed by date interaction, and catchment within watersheds (random effect); B) Nested split-plot experimental design included watershed (fixed) and catchment within watersheds (random effect). Presented are $F$ value, degrees of freedom (DF), probability $(P)$ of a value greater than $F$ in parentheses, and the estimated $R^{2}$ of the model. Significant relationships are highlighted in bold.

A. Repeated measures experimental design

\begin{tabular}{|c|c|c|c|c|}
\hline & & $\begin{array}{c}\mathrm{ANC} \\
\left(\mu \mathrm{eq} \mathrm{L}^{-1}\right)\end{array}$ & pH & $\begin{array}{l}\text { Molar } \\
\text { Ca:Al }\end{array}$ \\
\hline & $\mathrm{DF}$ & $\begin{array}{c}F \text {-value } \\
(P)\end{array}$ & $\begin{array}{c}F \text {-value } \\
(P)\end{array}$ & $\begin{array}{c}F \text {-value } \\
(P)\end{array}$ \\
\hline WS & 2 & $\begin{array}{c}6.50 \\
(0.01)\end{array}$ & $\begin{array}{c}2.20 \\
(0.15)\end{array}$ & $\begin{array}{c}14.72 \\
(<0.001)\end{array}$ \\
\hline DATE & 3 & $\begin{array}{l}1.55 \\
(0.22)\end{array}$ & $\begin{array}{c}0.71 \\
(0.55)\end{array}$ & $\begin{array}{c}9.39 \\
(<0.001)\end{array}$ \\
\hline WS $\times$ D & 6 & $\begin{array}{c}5.84 \\
(<0.001)\end{array}$ & $\begin{array}{c}1.76 \\
(0.14)\end{array}$ & $\begin{array}{c}0.14 \\
(0.99)\end{array}$ \\
\hline Model $\boldsymbol{R}^{2}$ & & 0.56 & 0.26 & 0.63 \\
\hline
\end{tabular}

B. Nested split-plot experimental design

\begin{tabular}{ccccc}
\hline & & $\begin{array}{c}\text { ANC } \\
\left(\boldsymbol{\mu e q ~ ~ ^ { - 1 } )}\right.\end{array}$ & $\mathbf{p H}$ & $\begin{array}{c}\text { Molar } \\
\text { Ca:Al }\end{array}$ \\
\hline & DF & $\begin{array}{c}F \text {-value } \\
(P)\end{array}$ & $\begin{array}{c}F \text {-value } \\
(P)\end{array}$ & $\begin{array}{c}F \text {-value } \\
(P)\end{array}$ \\
\hline WS & 2 & $\mathbf{3 . 7 5}$ & 2.28 & $\mathbf{1 5 . 1 7}$ \\
& & $(\mathbf{0 . 0 5})$ & $(0.14)$ & $(<\mathbf{0 . 0 0 1 )}$
\end{tabular}

\begin{tabular}{llll}
\hline Model $\boldsymbol{R}^{\mathbf{2}}$ & 0.38 & 0.28 & 0.72 \\
\hline
\end{tabular}


Table 3. Catchment variables included as covariates in the statistical models examining the variability in stream chemistry for ANC, pH and molar Ca:Al ratio. Covariates listed were included in the model with $P$-value $\leq 0.05$. Covariate variables designated '*' were significant in the split plot experimental design and "**” in the repeated measures analysis. The estimated model $R^{2}$ incorporates the nested split-plot or repeated measures models as presented in Table 2 with the improvement in predictions by including covariate(s).

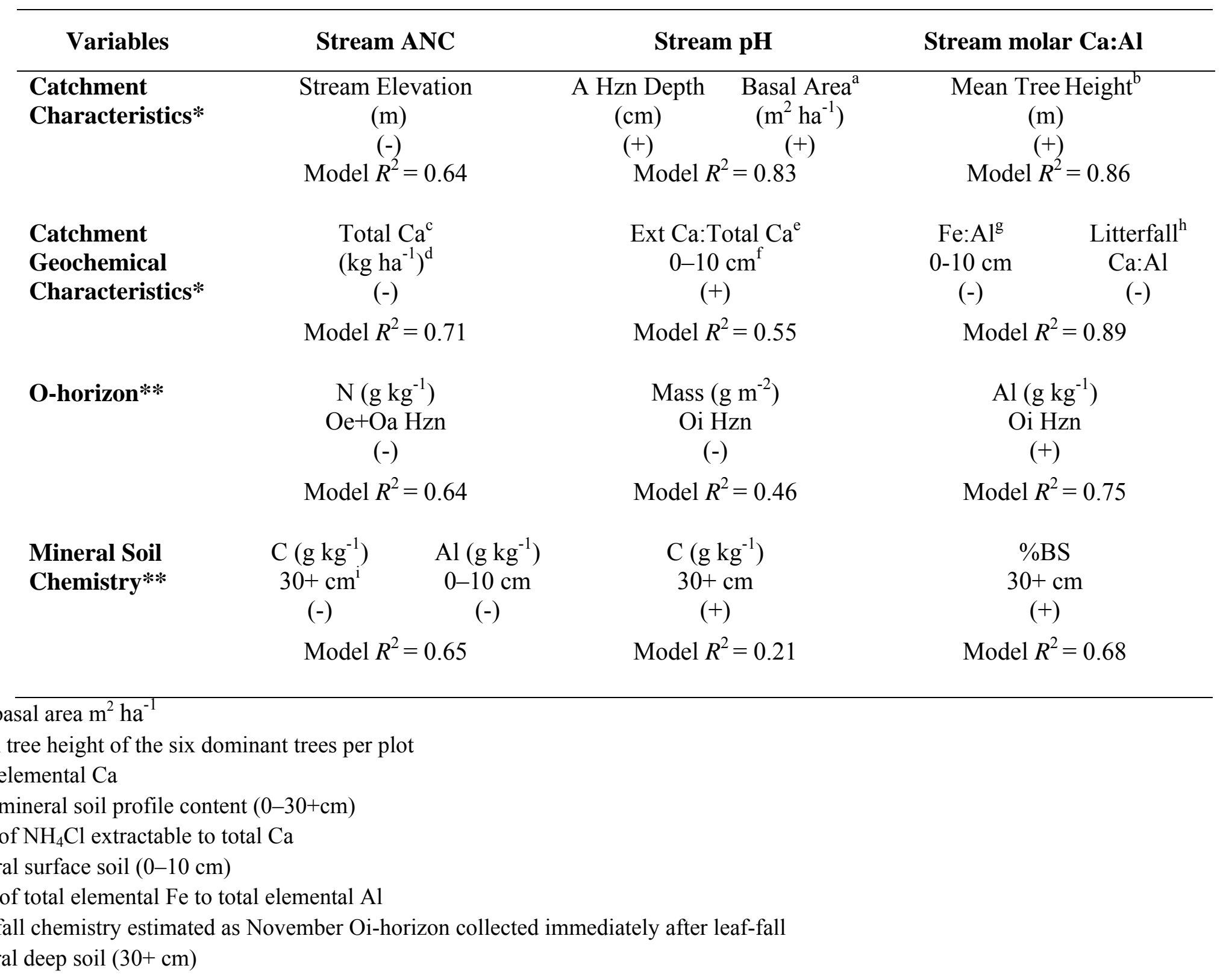


Table 4. Riparian plot variables from that were included as covariates in the statistical model examining the variability in stream chemistry, for ANC, $\mathrm{pH}$ and molar Ca:Al ratio. Covariates listed were included in the model with $P$-value $\leq 0.05$. 'NS' indicates analyses in which no significant covariates were identified. Covariate variables designated ' $*$ ' were significant in the nested split-plot experimental design and '**” in the repeated measures analysis. The estimated model $R^{2}$ incorporates the split-plot or repeated measures models as presented in Table 2 with the improvement in predictions by including covariate(s).

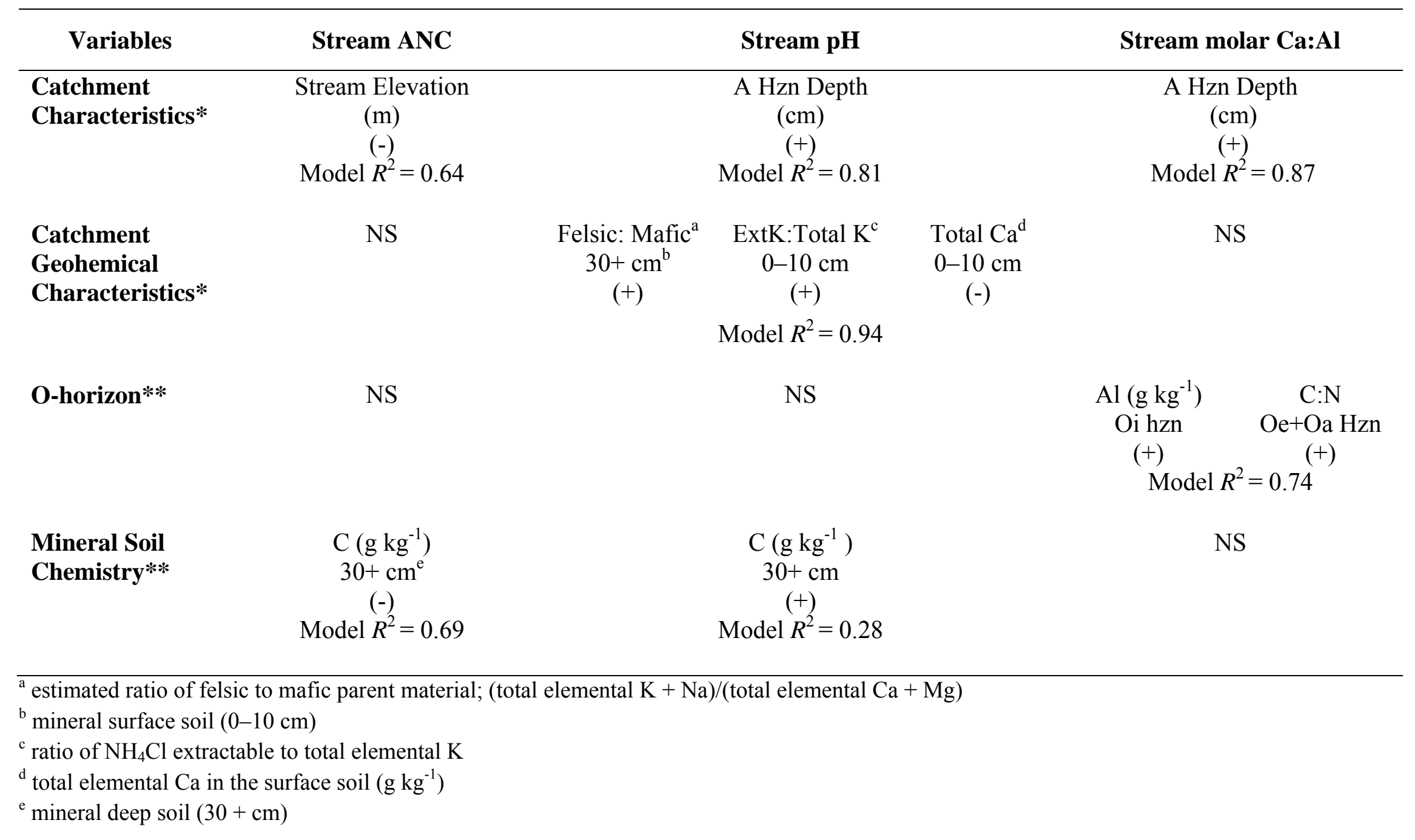


Figure 1

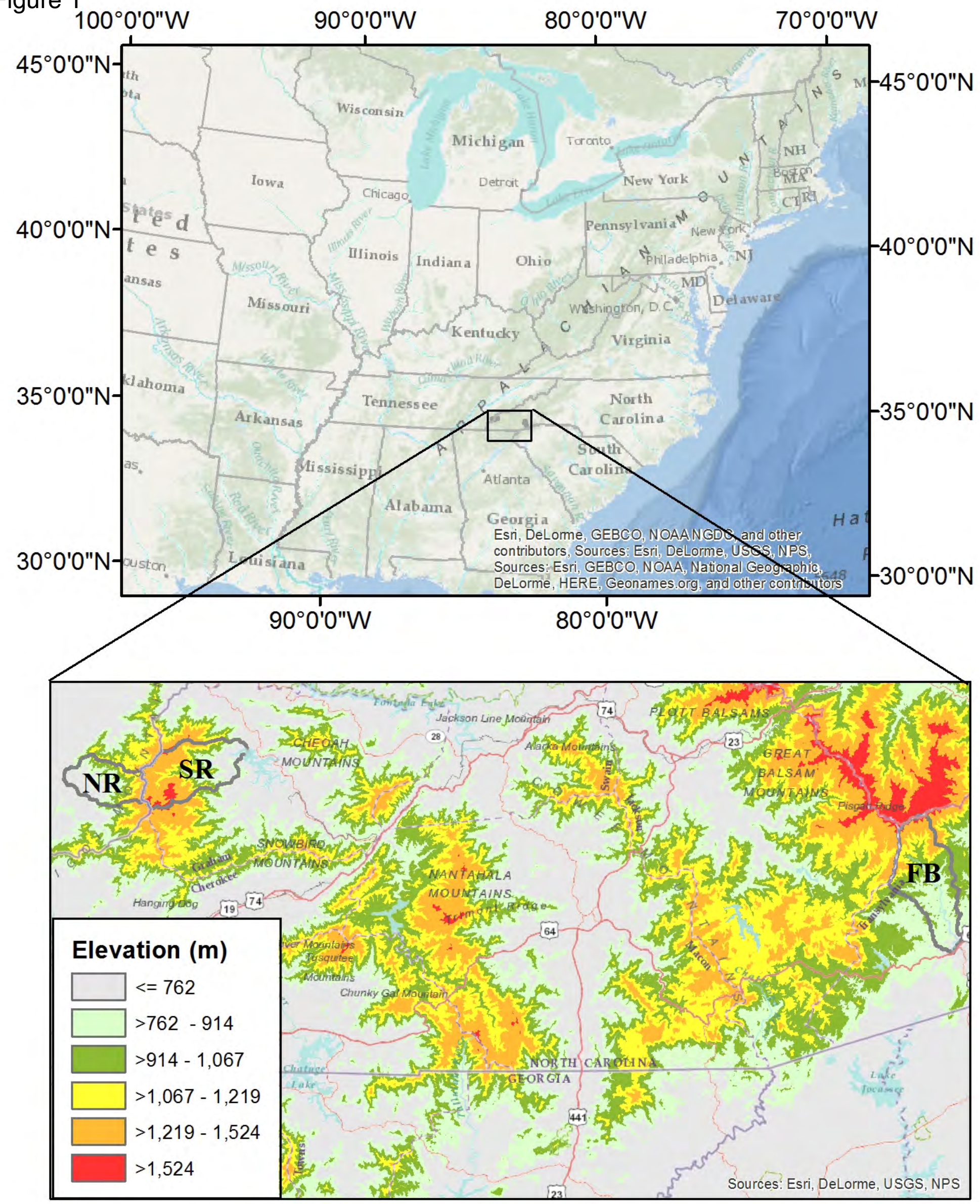


Figure $2_{40}$
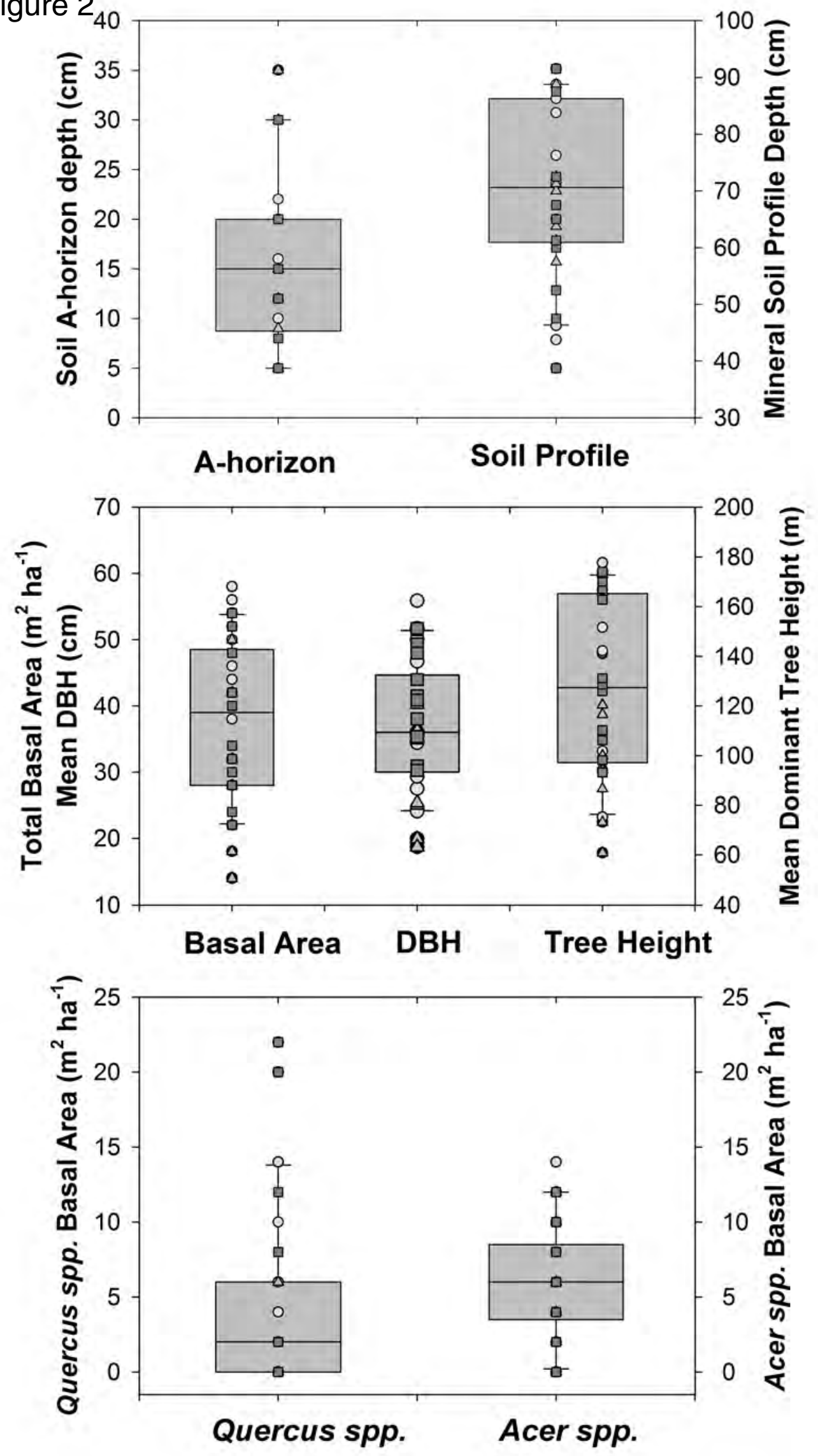
Figure 3

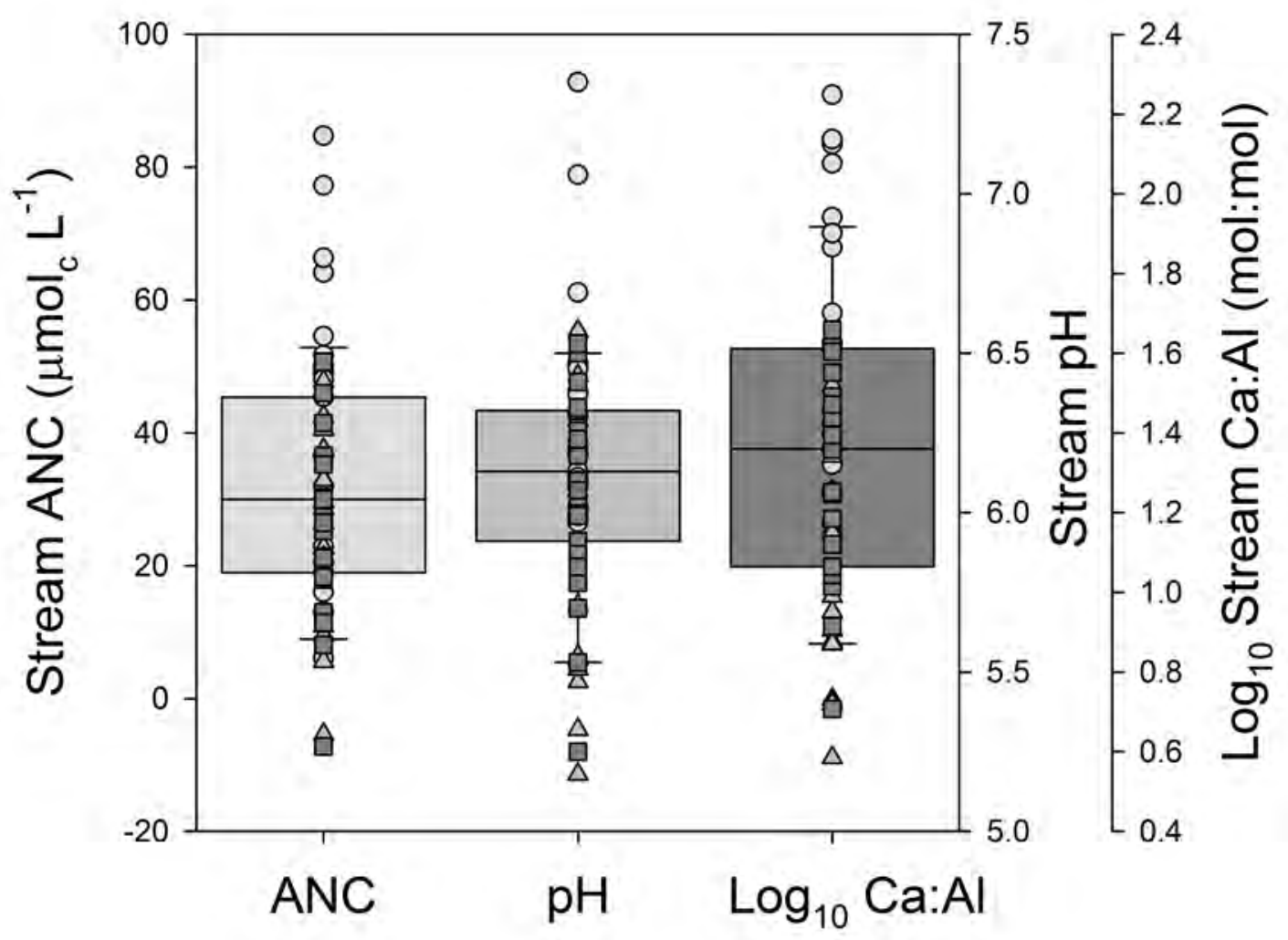


Figure 4
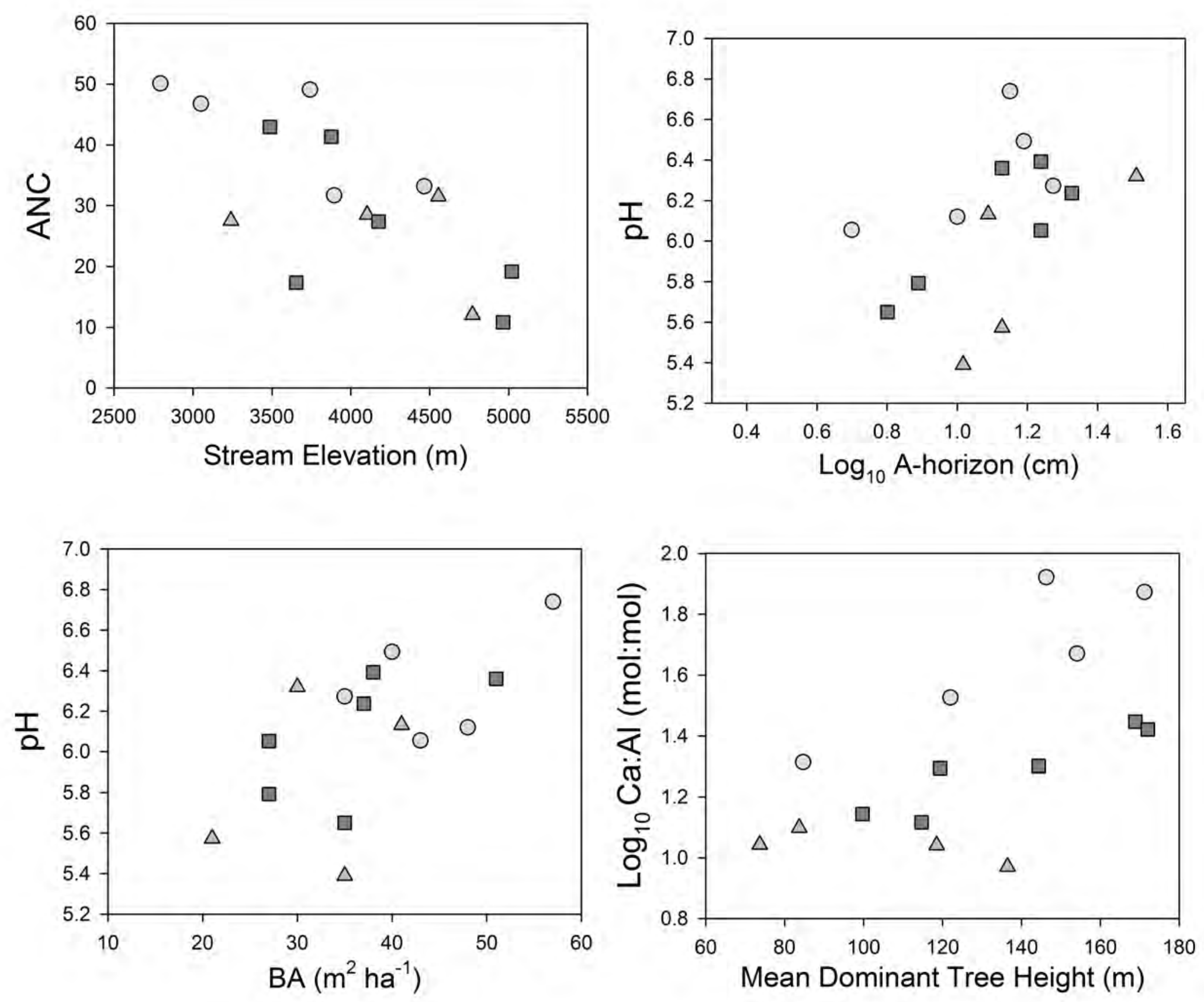
Figure 5
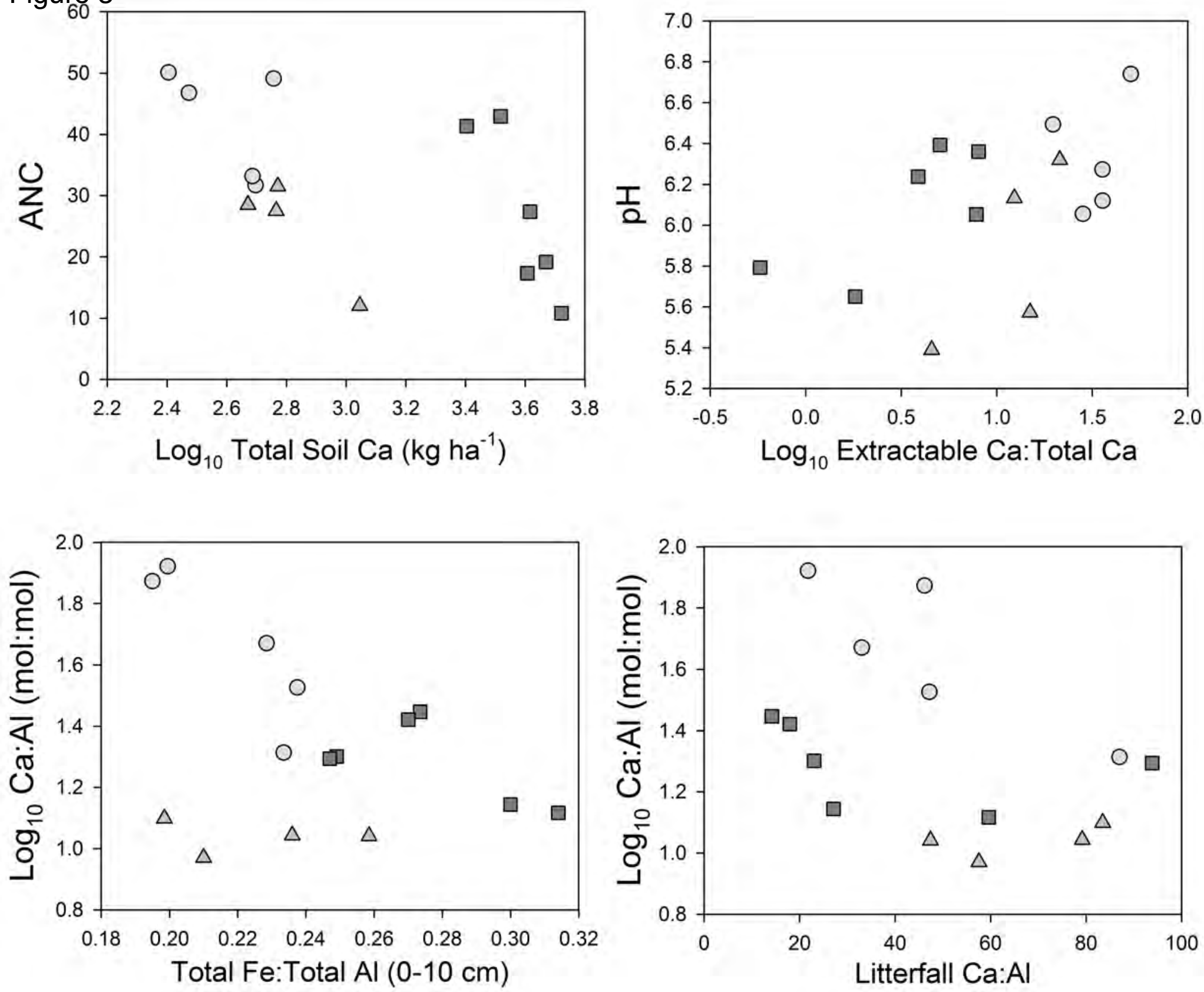
Figure 6

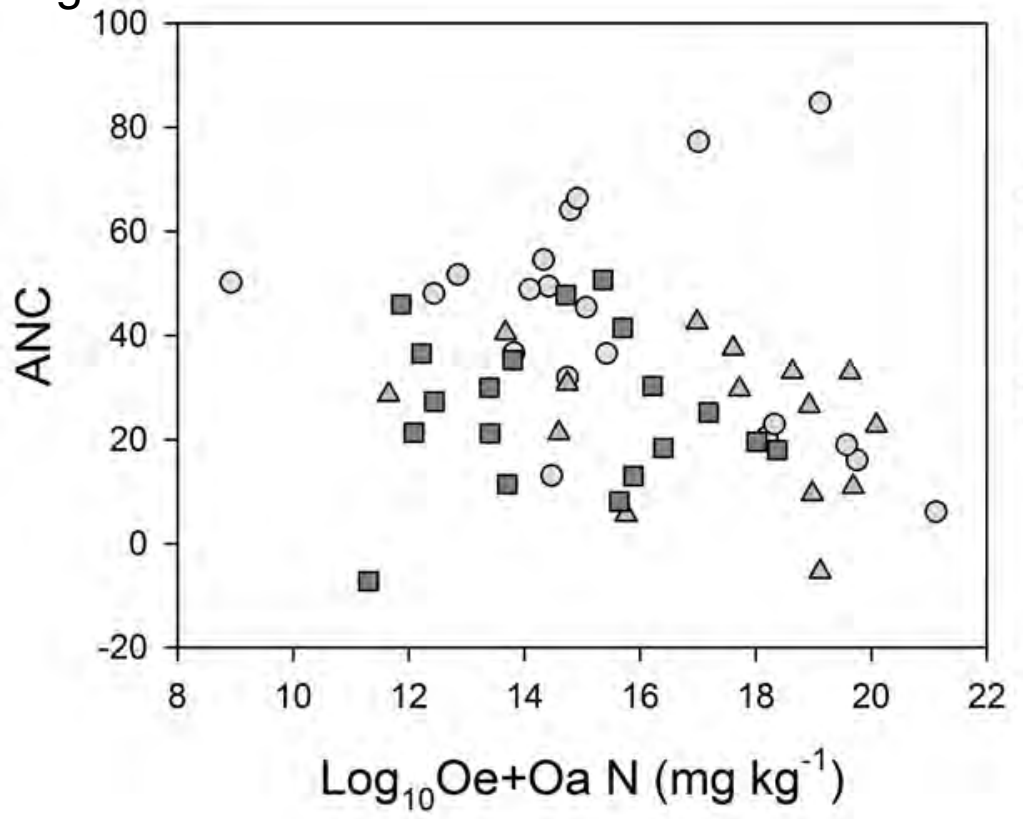

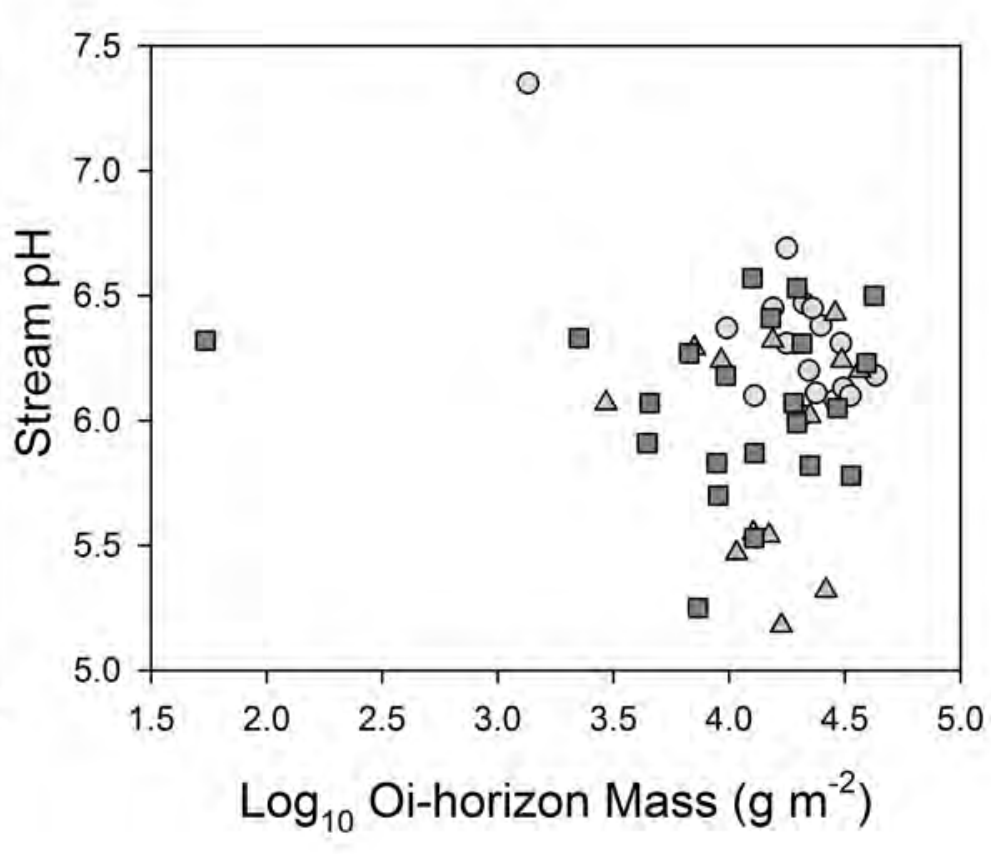




\section{Figure 7}

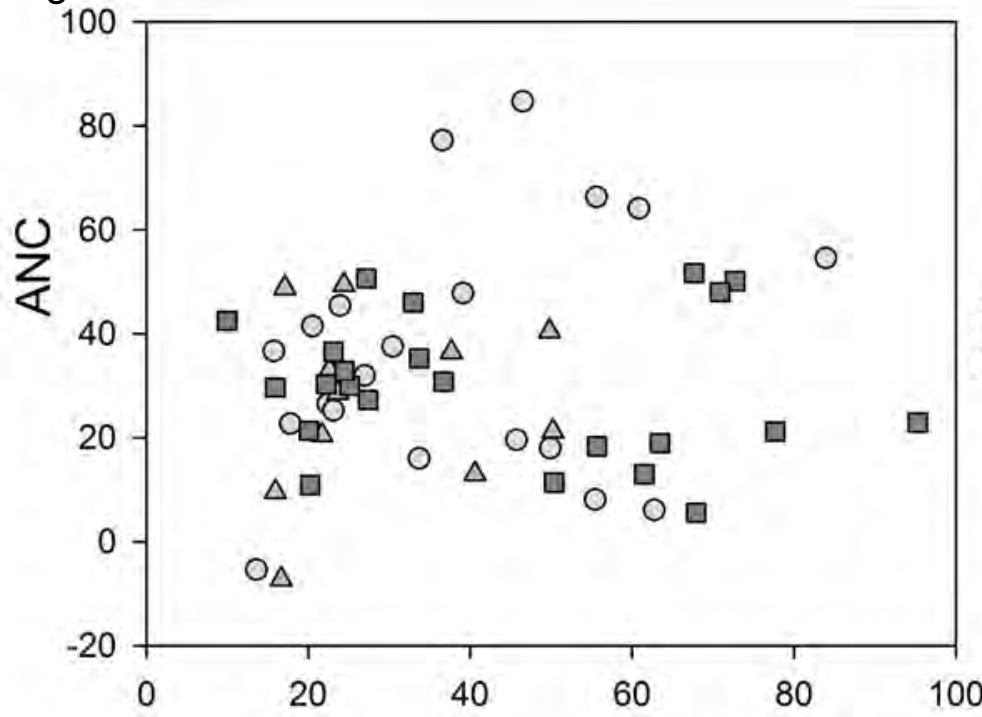

Total C $(30+\mathrm{cm})\left(\mathrm{g} \mathrm{kg}^{-1}\right)$

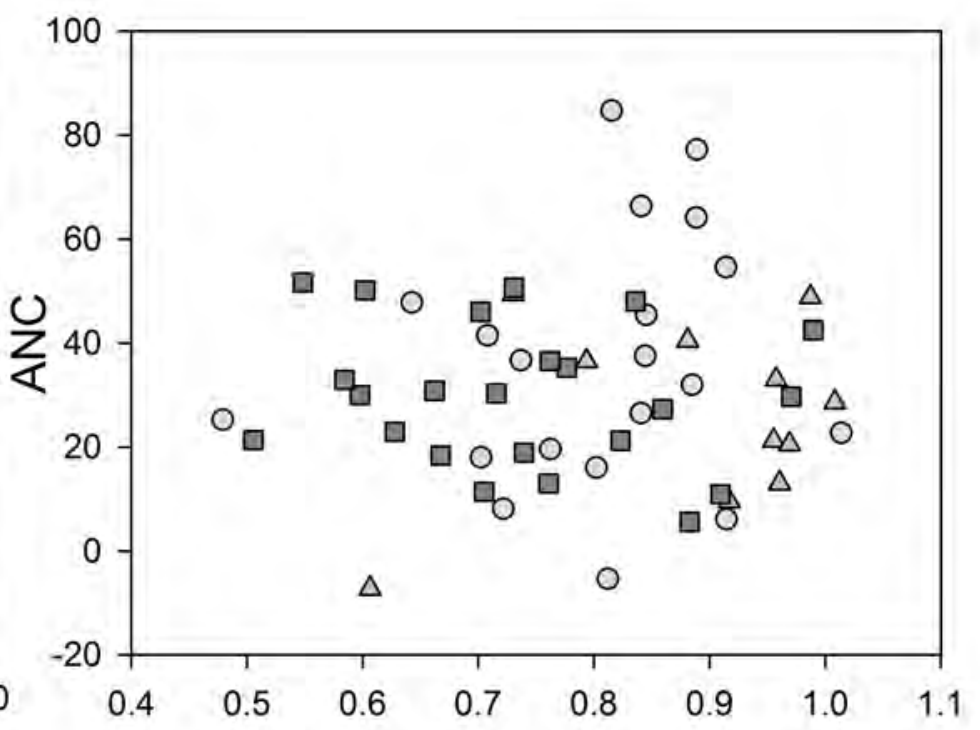

$\log _{10}$ Soil extractable Al $(0-10 \mathrm{~cm})$
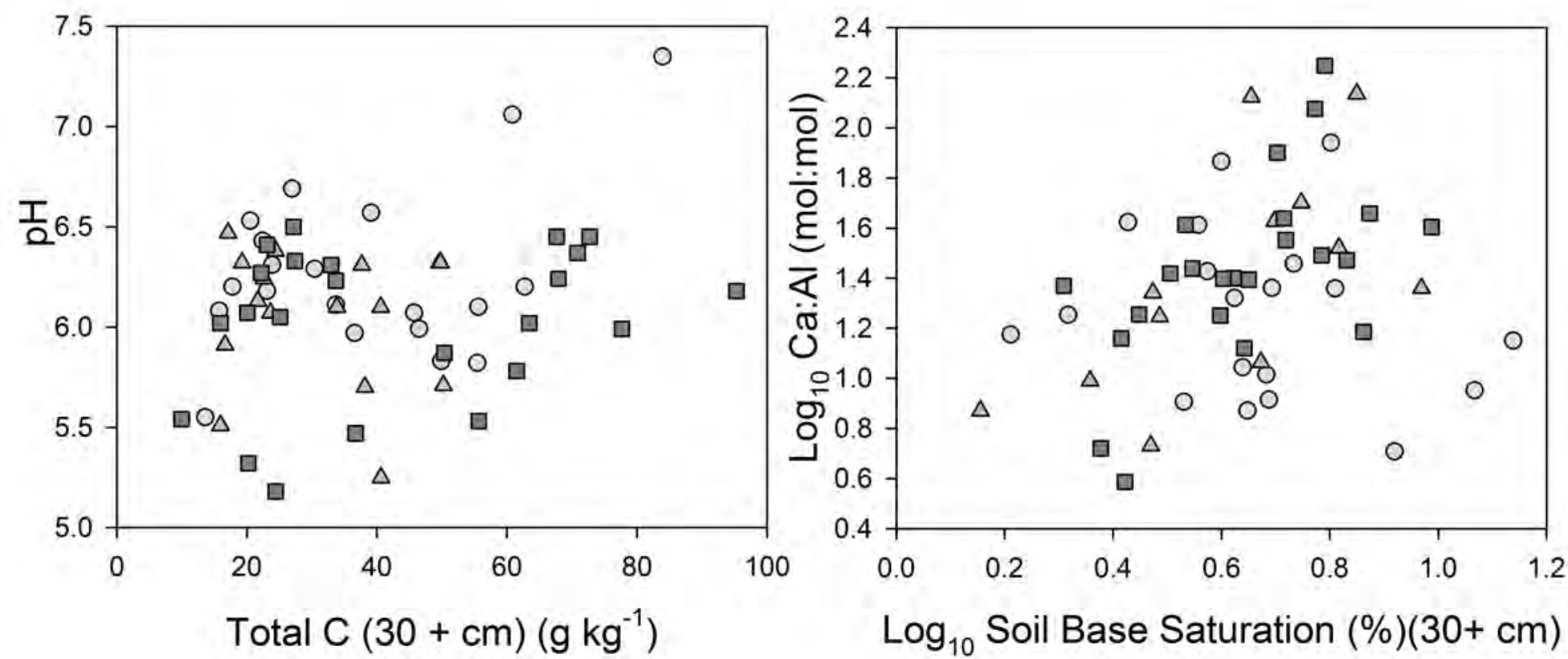

$\log _{10}$ Soil Base Saturation $(\%)(30+\mathrm{cm})$ 
Figure 8

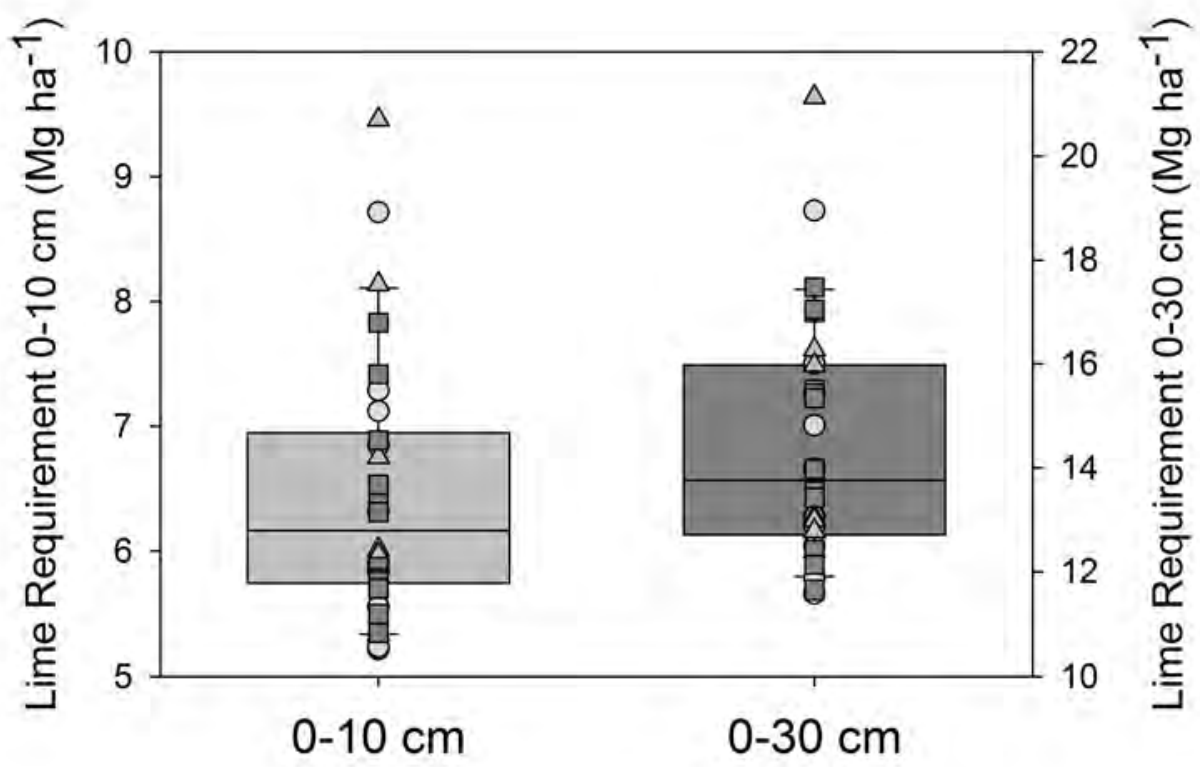


Figure 9
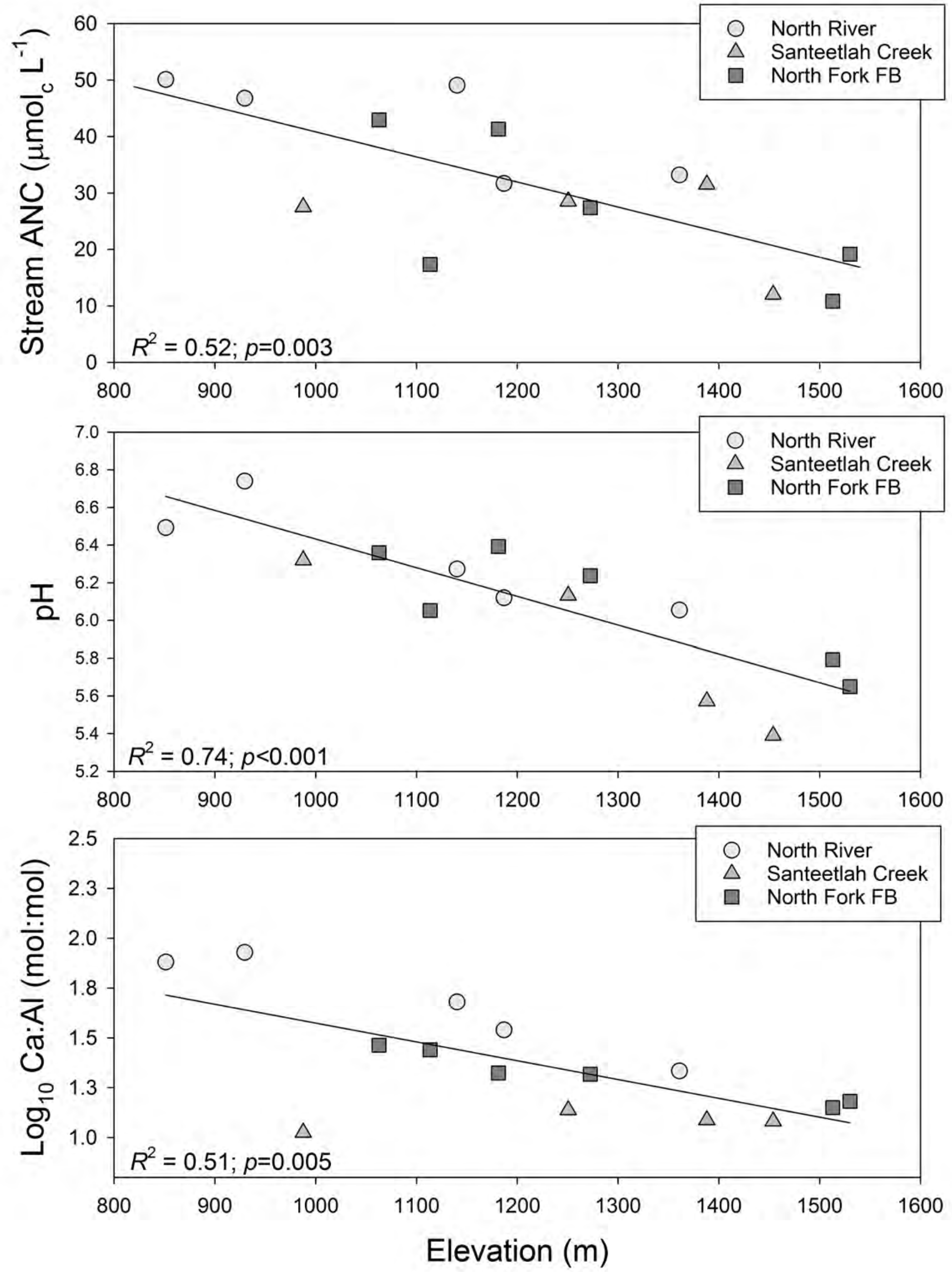